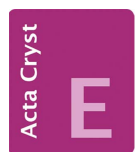

CRYSTALLOGRAPHIC COMMUNICATIONS

ISSN 2056-9890

Received 24 June 2017

Accepted 3 July 2017

Edited by W. T. A. Harrison, University of Aberdeen, Scotland

Keywords: crystal structure; drug design; chromones; conformation; supramolecular structure.

CCDC references: 1560084; 1517021

Supporting information: this article has supporting information at journals.iucr.org/e

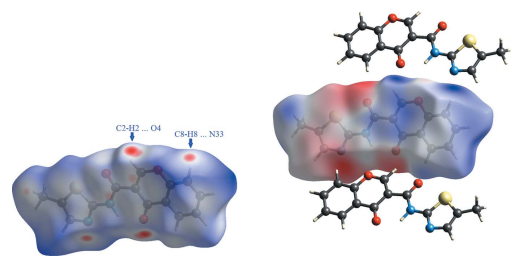

OPEN $\odot$ ACCESS

\section{Polymorphism in the structure of $\mathrm{N}$-(5-methylthia- zol-2-yl)-4-oxo-4H-chromene-3-carboxamide}

\author{
Ligia R. Gomes, ${ }^{a}$ John Nicolson Low, ${ }^{b *}$ Fernando Cagide $^{c}$ and Fernanda Borges ${ }^{c}$ \\ aFP-ENAS-Faculdade de Ciências de Saúde, Escola Superior de Saúde da UFP, Universidade Fernando Pessoa, Rua Carlos \\ da Maia, 296, P-4200-150 Porto, Portugal, 'b Department of Chemistry, University of Aberdeen, Meston Walk, Old \\ Aberdeen, AB24 3UE, Scotland, and ${ }^{\mathrm{C}} \mathrm{CIQ} /$ Departamento de Quımica e Bioquımica, Faculdade de Ciências, \\ Universidade do Porto, 4169-007 Porto, Portugal. *Correspondence e-mail: jnlow111@gmail.com
}

Chromone derivatives have been extensively studied recently because of to their promising biological activities. The new title chromone-thiazole hybrid presented here, $\mathrm{C}_{14} \mathrm{H}_{10} \mathrm{~N}_{2} \mathrm{O}_{3} \mathrm{~S}$, is a candidate as a selective ligand for adenosine receptors. The compound has been synthesized and characterized by the usual spectroscopic means (NMR and EM/IE) and its structure elucidated by X-ray crystallography, which revealed the presence of packing polymorphism. The two polymorphs (one with space group $P 2_{1} / n$ and one with $P 2_{1} / c$ ) show slightly different conformations and the major change induced by crystallization regards the intramolecular contacts defining the supramolecular structure. Those differences been highlighted by Hirshfeld surface analysis mapped over $d_{\text {norm }}$ and ESP.

\section{Chemical context}

Chromones are $4 H$-benzopyran-4-one heterocycles and they have been studied thoroughly because of their interesting biological activities (Gaspar et al., 2012a,b; 2014) Thiazolebased compounds have been used in therapeutics as antimicrobial, antiviral and antifungal agents for a long time (Souza, 2005; Siddiqui et al., 2009) but, in the past decades, they have been identified as potent and selective ligands for the adenosine receptor (Sharma et al. 2009; Jung et al., 2004). In a continuation of our project related to the synthesis of pharmacologically useful heterocycles, the title compound has been designed as a potential ligand for human adenosine receptors.

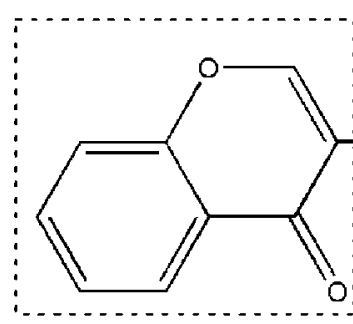

A

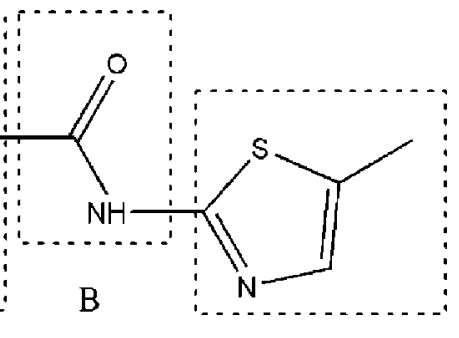

$\mathrm{C}$
This work reports the synthesis and structural characterization of this chromone-thiazole hybrid, $N$-(5-methylthiazol2-yl)-4-oxo- $4 H$-chromene-3-carboxamide, $\mathbf{1}$, that was synthesized following a method previously described by Cagide $e t$ al. (2015). The chromone ring $(A)$ is connected to the thiazole ring $(C)$ though a carboxamide spacer $(B)$. The compound crystallizes with two different morphologies and the structural 
Table 1

Hydrogen-bond geometry $\left(\AA,^{\circ}\right)$ for $P 2_{1} / n$.

\begin{tabular}{lllll}
\hline$D-\mathrm{H} \cdots A$ & $D-\mathrm{H}$ & $\mathrm{H} \cdots A$ & $D \cdots A$ & $D-\mathrm{H} \cdots A$ \\
\hline $\mathrm{N} 3-\mathrm{H} 3 \cdots \mathrm{O} 4$ & 0.88 & 1.96 & $2.687(5)$ & 139 \\
$\mathrm{C} 2-\mathrm{H} 2 \cdots \mathrm{O} 4{ }^{\mathrm{i}}$ & 0.95 & 2.38 & $3.030(5)$ & 126 \\
$\mathrm{C} 8-\mathrm{H} 8 \cdots \mathrm{N}^{\mathrm{i}} 3^{\mathrm{i}}$ & 0.95 & 2.56 & $3.455(6)$ & 157
\end{tabular}

Symmetry code: (i) $-x+\frac{1}{2}, y+\frac{1}{2},-z+\frac{1}{2}$.

analysis revealed the presence of packing polymorphism. Since this compound will be assayed in tests to evaluate its biological activity, the establishment of the polymorphic structures is of the utmost importance.

\section{Structural commentary}

The molecular structures of the polymorphs are shown in Fig. 1. This compound presents packing polymorphism and crystallizes in monoclinic space groups $P 2_{1} / n$ and $P 2_{1} / c$, the latter with two molecules in the asymmetric unit (identified as mol\#1 and mol\#2). In $\mathbf{1} \_\boldsymbol{P 2} / \boldsymbol{c}$, mol\#1 fits into mol\#2 with values of quaternion fit weighted of $0.093 \AA$ (unit-weight r.m.s. fit of $0.086 \AA$ for 20 atoms).

The conformation around the amide rotamer for chromone carboxamides can be either -anti or -syn. The former appears to be more probable since it lowers the steric hindrance between the two aromatic rings as compared to the -syn rotamer. Structural characterizations made previously in other 4H-chromene-3-carboxamides (Gomes et al., 2015a,b) show that, when the amide oxygen atom $(\mathrm{O} 3 / \mathrm{O} 13 / \mathrm{O} 23)$ is transrelated to the pyran oxygen atom of the chromone (O1/O11/ $\mathrm{O} 21)$ the -anti conformation predominates since it permits the
Table 2

Hydrogen-bond geometry $\left(\AA,^{\circ}\right)$ for 1_P2 1 _c.

\begin{tabular}{lllll}
\hline$D-\mathrm{H} \cdots A$ & $D-\mathrm{H}$ & $\mathrm{H} \cdots A$ & $D \cdots A$ & $D-\mathrm{H} \cdots A$ \\
\hline $\mathrm{N} 13-\mathrm{H} 13 \cdots \mathrm{O} 14$ & $0.80(4)$ & $1.99(4)$ & $2.671(3)$ & $143(4)$ \\
$\mathrm{C} 12-\mathrm{H} 12 \cdots \mathrm{O} 24^{\text {i }}$ & 0.95 & 2.27 & $2.963(4)$ & 129 \\
$\mathrm{C} 15-\mathrm{H} 15 \cdots \mathrm{O} 23^{\text {ii }}$ & 0.95 & 2.43 & $3.353(4)$ & 164 \\
$\mathrm{C} 136-\mathrm{H} 13 C \cdots \mathrm{O} 13^{\text {iii }}$ & 0.98 & 2.51 & $3.449(4)$ & 162 \\
$\mathrm{~N} 23-\mathrm{H} 23 \cdots \mathrm{O} 24$ & $0.82(4)$ & $2.05(3)$ & $2.697(3)$ & $136(3)$ \\
$\mathrm{C} 22-\mathrm{H} 22 \cdots \mathrm{O} 14^{\text {ii }}$ & 0.95 & 2.19 & $2.999(4)$ & 142 \\
$\mathrm{C}^{\text {iv }}-\mathrm{H} 25 \cdots \mathrm{O} 13^{\text {iv }}$ & 0.95 & 2.48 & $3.352(4)$ & 153 \\
\hline
\end{tabular}

Symmetry codes: (i) $x+1,-y+\frac{1}{2}, z+\frac{1}{2}$

(ii) $\quad x,-y+\frac{1}{2}, z+\frac{1}{2}$;

$-x+1,-y+1,-z+1$; (iv) $x-1,-y+\frac{1}{2}, z-\frac{1}{2}$.

establishment of a short intramolecular $\mathrm{N}-\mathrm{H} \cdots \mathrm{O}$ (carbonyl) hydrogen bond (geometric parameters for the intramolecular $\mathrm{H}$ bond are given in Tables 1 and 2), which generates an $S(6)$ ring.

The $\mathrm{S}$ atom of the thiazole ring is in a -cis position with respect to the carbonyl $\mathrm{O} 3 / \mathrm{O} 23 / \mathrm{O} 13$ atom of the amide in both polymorphs. This feature has also been observed for similar compounds (Cagide et al., 2015). Gas-phase ab initio geometry optimization and natural atomic charges obtained by population analysis [using natural bond orbital (NBO) analysis] revealed that negative charges are located at the two nitrogen atoms and at the three oxygen atoms, while the positive charges reside at the amide carbon atom as well as at the sulfur atom of the thiazole ring, suggesting that a further stabilization may arise when the $\mathrm{S}$ atom is pointing to the carboxyl oxygen atom of the amide. This was also confirmed here by similar calculations: the results obtained for atomic charges by NBO analysis, performed after single-point energy calculation, are in Fig. 2. In addition, the calculation of energies and charges of several conformers, obtained by rotation of the
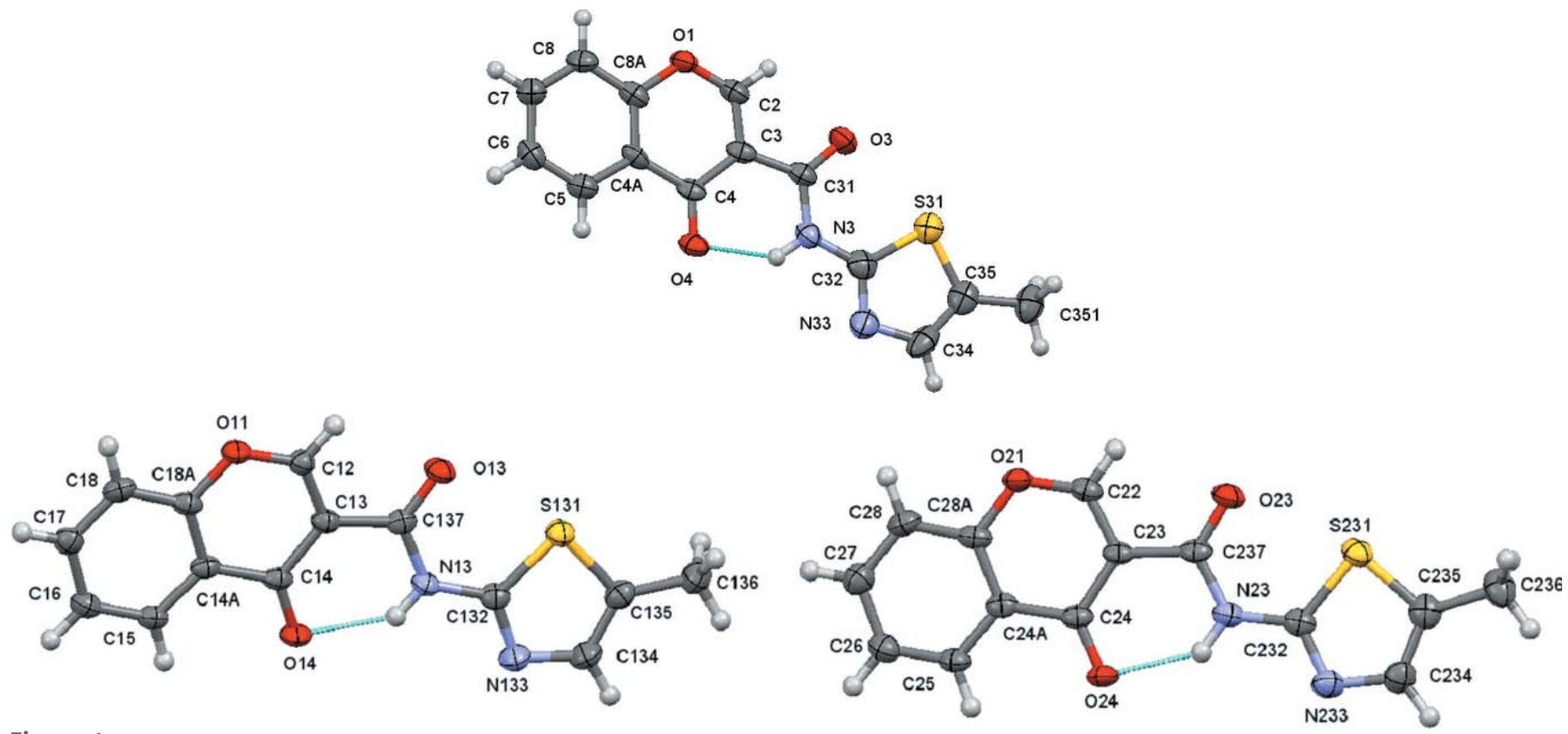

Figure 1

A view of the asymmetric unit of $\mathbf{1} \_\boldsymbol{P 2} / \boldsymbol{n}$ with the atom-numbering scheme (top). A view of the asymmetric unit of $\mathbf{1} \_\boldsymbol{P 2} / \boldsymbol{c}$ with mol\#1 (left) and mol\#2 (right) with the atom-numbering scheme (bottom). Displacement ellipsoids are drawn at the $70 \%$ probability level. 
Table 3

Dihedral angles $\left(^{\circ}\right)$.

$\theta_{\mathrm{A}-\mathrm{C}}$ is the dihedral angle between the mean planes of the chromene and phenyl ring and the thiazole ring. $\theta_{\mathrm{A}-\mathrm{B}}$ is the dihedral angles between the mean planes of the chromone ring and the plane defined by the $\mathrm{O} 2 / \mathrm{C} 21 / \mathrm{N} 2$ atoms. $\theta_{\mathrm{B}-\mathrm{C}}$ is the dihedral angle between the mean planes of the thiazole ring and the plane defined by the O3/C41/N3 atoms.

\begin{tabular}{|c|c|c|c|}
\hline Compound & $\theta_{\mathrm{A}-\mathrm{C}^{\circ}}$ & $\theta_{\mathrm{A}-\mathrm{B}}{ }^{\circ}$ & $\theta_{\mathrm{B}-\mathrm{C}}{ }^{\circ}$ \\
\hline $1 \_P 2_{1} / n$ & $3.1(2)$ & $1.6(8)$ & $4.5(8)$ \\
\hline $1 \_P 2_{1} / c(\mathrm{~mol} \# 1)$ & $6.38(9)$ & $5.12(19)$ & $1.76(12)$ \\
\hline $1 \_P 2_{1} / c(\mathrm{~mol} \# 2)$ & $3.42(10)$ & $1.43(10)$ & $2.01(14)$ \\
\hline
\end{tabular}

thiazole ring $(C)$ around the amide spacer $(B)$ were made, showing that the lowest energy is obtained when the sulfur atom is around $0^{\circ}$. Details are provided in the Supporting information.

Relevant data for the discussion of molecular geometry and conformation of the polymorphs is presented in Table $3 ; \theta_{\mathrm{A}-\mathrm{C}}$ refers to the dihedral angle between the mean planes of the chromone and thiazole rings, $\theta_{\mathrm{A}-\mathrm{B}}$ to the dihedral angle between the best plane of the chromone and the plane defined by atoms $\mathrm{OCN}$ of the amide moiety, whereas $\theta_{\mathrm{B}-\mathrm{C}}$ refers to the dihedral angle between this plane and the best plane of the thiazole ring. Since the heteroaromatic rings are practically planar, the dihedral angle $\theta_{\mathrm{A}-\mathrm{C}}$ quantifies the degree of bend and/or twist between them and can be used for evaluation of the distortion of the molecule from planarity when one of the dihedrals, $\theta_{\mathrm{A}-\mathrm{B}}$ or $\theta_{\mathrm{B}-\mathrm{C}}$, is relatively small. As seen, $\mathbf{1} \_\boldsymbol{P 2 _ { 1 }} / \boldsymbol{n}$ and $1 \_P 2_{1} / \boldsymbol{c} \_$mol $\# 2$ are practically planar while $\mathbf{1} \_\mathbf{P 2 1} / \mathbf{c} \_$mol\#1 presents a slightly higher $\theta_{\mathrm{A}-\mathrm{C}}$ angle due to the rotation of the chromone ring with respect to the amide plane.

\section{Supramolecular features}

\section{Molecular structure and conformation}

In $1 \_P 2_{1} / \boldsymbol{n}$ the molecules are linked by the $\mathrm{C} 2-\mathrm{H} 2 \cdots \mathrm{O} 4^{\mathrm{i}}$ and $\mathrm{C} 8-\mathrm{H} 8 \cdots \mathrm{N} 33^{\mathrm{i}}$ weak hydrogen bonds, Table 1 , which form a chain of $R_{2}^{2}$ (13) rings runing parallel to the $b$-axis direction generated by the twofold screw axis at $x=\frac{1}{4}$ and $y=\frac{1}{4}$, as depicted in Fig. 3.

The molecules in $\mathbf{1} \_\boldsymbol{P 2 _ { 1 }} / \boldsymbol{c}$ are linked by alternating weakly hydrogen-bonded $R_{2}^{2}(10)$ rings formed by the hydrogen bonds

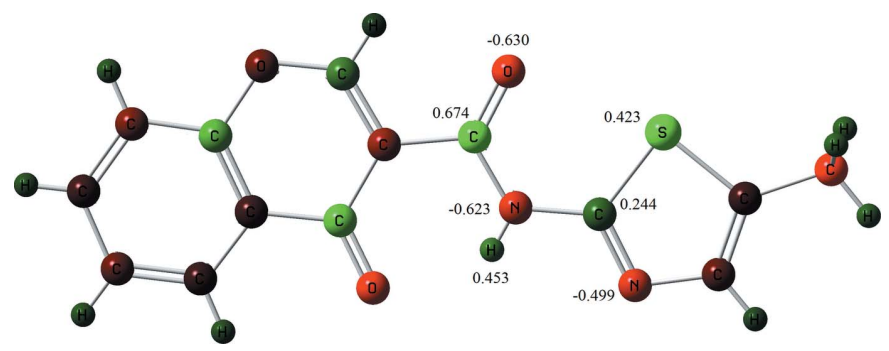

Figure 2

Natural atomic charges from population analysis (NBO), at the B3LYP/ 6-311+G(d) level of theory for the $\mathbf{1} \boldsymbol{P 2} / \boldsymbol{n}$ at crystal geometric conformation. The charge distributions are presented within a relative charge range of -1.000 (green) to +1.000 (light red).

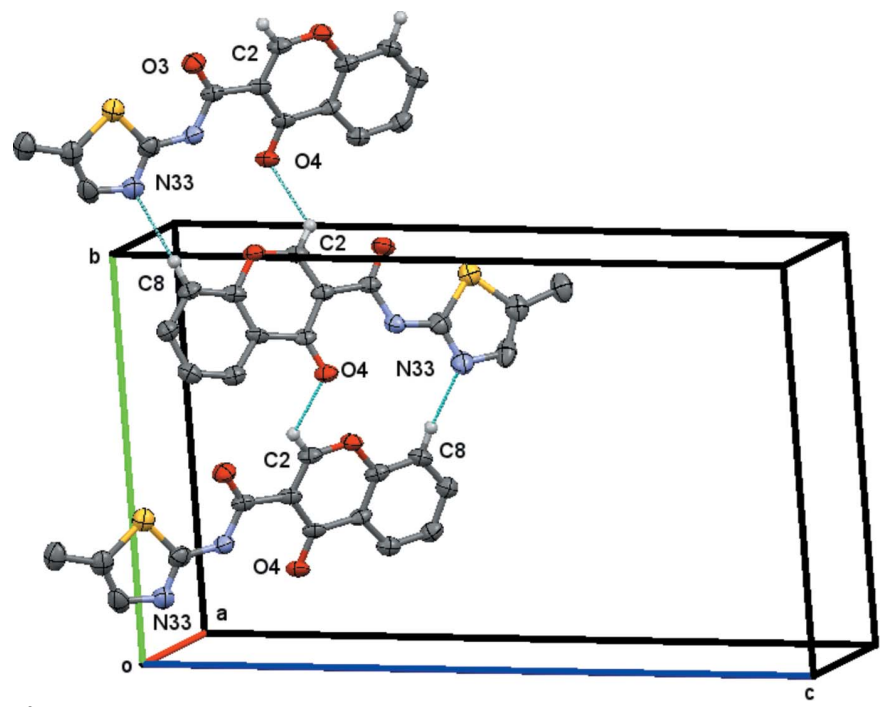

Figure 3

The chain of $R_{2}^{2}(13)$ rings running parallel to the $b$ axis generated by the twofold screw axis at $x=1 / 4$ and $y=1 / 4$ as depicted for $\mathbf{1} P \mathbf{P}_{\mathbf{1}} / \boldsymbol{n}$. H atoms not participating in hydrogen bonding have been omitted for the sake of clarity.

$\mathrm{C} 12-\mathrm{H} 12 \cdots \mathrm{O} 24^{\mathrm{ii}}$ and $\mathrm{C} 25-\mathrm{H} 25 \cdots \mathrm{O} 13^{\mathrm{iv}}$ in one case and $\mathrm{C} 22-\mathrm{H} 22 \cdots \mathrm{O} 14^{\mathrm{ii}}$ and $\mathrm{C} 15-\mathrm{H} 15 \cdots \mathrm{O} 23^{\mathrm{ii}}$ in the other, Table 2. These link the molecules to form a chain of rings running parallel to [101], Fig. 4. Details of the $\pi-\pi$ stacking are given in

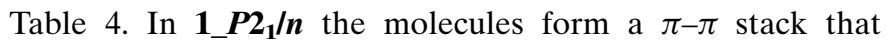
extends along the $a$ axis. In $\mathbf{1} \_P 2_{1} / c$, the two molecules in the asymmetric unit form a $\pi-\pi$ stacked dimer (which guided the choice of asymmetric unit). In both compounds, any possible $\mathrm{C}-\mathrm{H} \cdots \pi$ contacts involve methyl hydrogen atoms with $\mathrm{H} \cdots \pi$ distances in excess of $2.8 \AA$.

\section{Hirshfeld surfaces}

The Hirshfeld surfaces and two-dimensional fingerprint (FP) plots (Rohl et al., 2008) provide complementary information concerning the intermolecular interactions discussed above. They were generated using Crystal Explorer 3.1 (Wolff et al., 2012). The Hirshfeld surfaces, mapped over $d_{\text {norm }}$ (all scaled between -0.250 to 1.200 ) and the respective FP plots

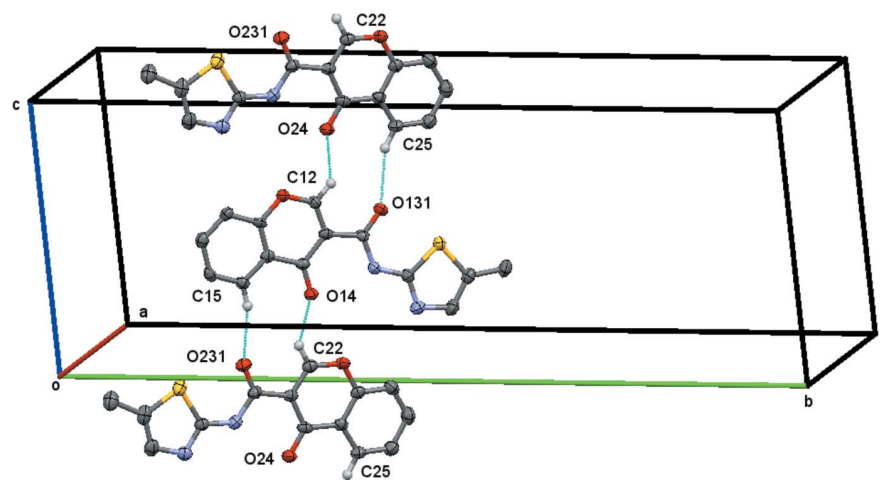

Figure 4

The molecules in $\mathbf{1} \_\boldsymbol{P 2}_{1} / \boldsymbol{c}$ linked by alternating weakly hydrogen-bonded $R_{2}^{2}(10)$ rings that lead the molecules to form a chain of rings running parallel to [101]. $\mathrm{H}$ atoms not participating in hydrogen bonding have been omitted for the sake of clarity. 
Table 4

Selected $\pi-\pi$ contacts $(\AA)$.

$C g I(J)=$ Plane number $I(J), C g I \_$Perp $=$perpendicular distance of $C g(I)$ on ring $J, C g J \_$Perp $=$perpendicular distance of $C g(J)$ on ring $I$, slippage $=$ distance between $C g(I)$ and perpendicular projection of $C g(J)$ on Ring $I$.

\begin{tabular}{|c|c|c|c|c|c|c|}
\hline Compound & $C g I$ & $C g J(\operatorname{aru})$ & $C g \cdots C g$ & CgI_Perp & CgJ_Perp & Slippage \\
\hline $1 \_P 2_{1} / n$ & $C g 1$ & $\operatorname{Cg} 2(x+1, y, z)$ & $3.547(3)$ & $3.3358(18)$ & 3.3299 (19) & 1.222 \\
\hline $1 \_P 2_{1} / c$ & $\mathrm{Cg} 3$ & $C g 4(x, y, z)$ & $3.6726(17)$ & $3.2645(13)$ & $3.3012(12)$ & 1.609 \\
\hline
\end{tabular}

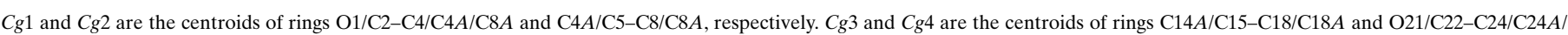
$\mathrm{C} 28 A$, respectively.

are depicted in Figs. 5 and 6 for $\mathbf{1} \_\boldsymbol{P 2} / \boldsymbol{n}$ and in Figs. 7 and 8 for 1_P21 $/ \boldsymbol{c}$; mol_\#1 and mol_\#2. Also in Figs. 5 and 9, the Hirshfeld surfaces mapped over the electrostatic potential (ESP) are depicted for both polymorphs. The contributions from various contacts, listed in Table 5, were selected by the partial analysis of those FP plots. Taking out the $\mathrm{H} \cdots \mathrm{H}$ contacts on the surface that are inherent to organic molecules, the most significant contacts can be divided in three groups: (i) the $\mathrm{H} \cdots \mathrm{O} / \mathrm{N}$ contacts that correspond to some relevant $\mathrm{C}-$ $\mathrm{H} \cdots \mathrm{O}, \mathrm{C}-\mathrm{H} \cdots \mathrm{N}$ intermolecular interactions; (ii) the $\mathrm{H} \cdots \mathrm{C} /$ C. $\cdot \mathrm{H}$ contacts and (iii) C. C contacts that are related to $\pi-\pi$ stacking. The structure has two carboxyl groups and a nitrogen atom of the thiazole that can act as acceptors for hydrogen bonding and a $\mathrm{N}-\mathrm{H}$ (amide) that can act as donor. In spite of that, the $\mathrm{N}-\mathrm{H}$ amide does not have a relevant role in the definition of the supramolecular structure but it is compromised in the intermolecular hydrogen bond.

\section{$\boldsymbol{P 2} / \boldsymbol{n}$ polymorph}

As seen in Fig. 3, in $\mathbf{1} \_\boldsymbol{P 2} / \boldsymbol{n}$ the oxygen atom O4 acts as acceptor for the hydrogen atom $\mathrm{H} 2$ of the chromone and the nitrogen atom N33 of the thiazole ring acts as acceptor for the
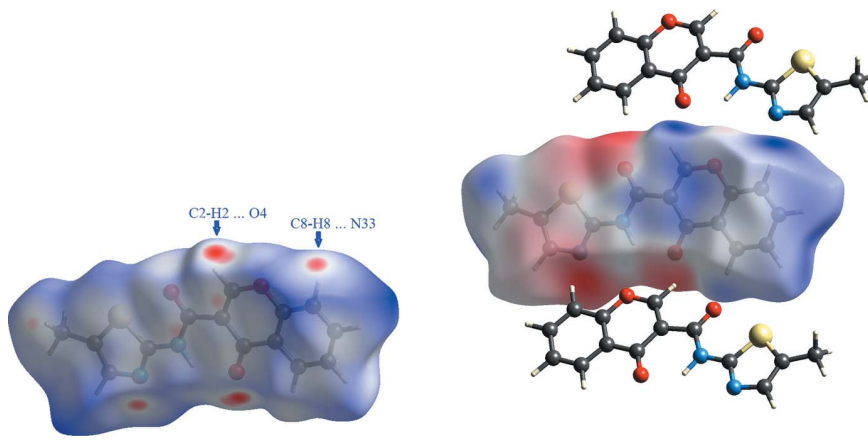

Figure 5

Views of the Hirshfeld surface mapped over $d_{\text {norm }}$ (left) and mapped over the electrostatic potential (right) for $\mathbf{1}_{-} \boldsymbol{P 2}_{1} / \boldsymbol{n}$. The highlighted red spots on the top face of the surfaces indicate contact points with the atoms participating in the $\mathrm{C}-\mathrm{H} \cdots \mathrm{O} / \mathrm{N}$ intermolecular interactions whereas those on the middle of the surface corresponds to $\mathrm{C} \cdots \mathrm{C}$ contacts as a consequence of the $\pi-\pi$ stacking. The electrostatic potential surface (ranging from -0.077 to 0.066 ) shows the complementary electronegative (red) and electropositive areas (blue) with molecules of the first shell. They depict the importance of the $\mathrm{H} 2$ and $\mathrm{H} 8$ atoms of the chromone ring that are located in the most electropositive area and their connection to $\mathrm{O} 4$ and N33. The methyl group presents also an electropositive region that complements with the thiozole environment near the sulfur atom.
H8 hydrogen atom of the chromone ring. Thus, the Hirshfeld surface of $1 \_\boldsymbol{P 2} / \boldsymbol{n}$ (mapped with $d_{\text {norm }}$ ) shows two sets of complementary red spots in the lateral faces of the surface as highlighted in Fig. 5, left. The small red-spot areas facing the chromone plane are due to C. .C contacts (that assume $7.1 \%$ of the contact area) and they correspond to the light-blue area in the middle of the FP plot, Fig. 6. The geometric parameters for these contacts are listed in Tables 3 and 5. The weak C $\cdots H$ contacts correspond to $15.2 \%$ of the surface area. The FP plot shows three sets of spikes pointing to southwest: the outer ones are due to the $\mathrm{H} \cdots \mathrm{N}$ contacts that involves the $\mathrm{N}$ (thiazole) $\cdot \cdot \mathrm{H} 8-\mathrm{C} 8$ (chromone) followed by the spikes corresponding to $\mathrm{O} \cdots \mathrm{H}$ contacts that englobes the $\mathrm{O} 4 \cdots \mathrm{H} 2-\mathrm{C} 2$ contacts and the inner one is due to close $\mathrm{S} \cdot \mathrm{H}$ contacts where the closest one is with the $\mathrm{H}$ atoms of the methyl group.

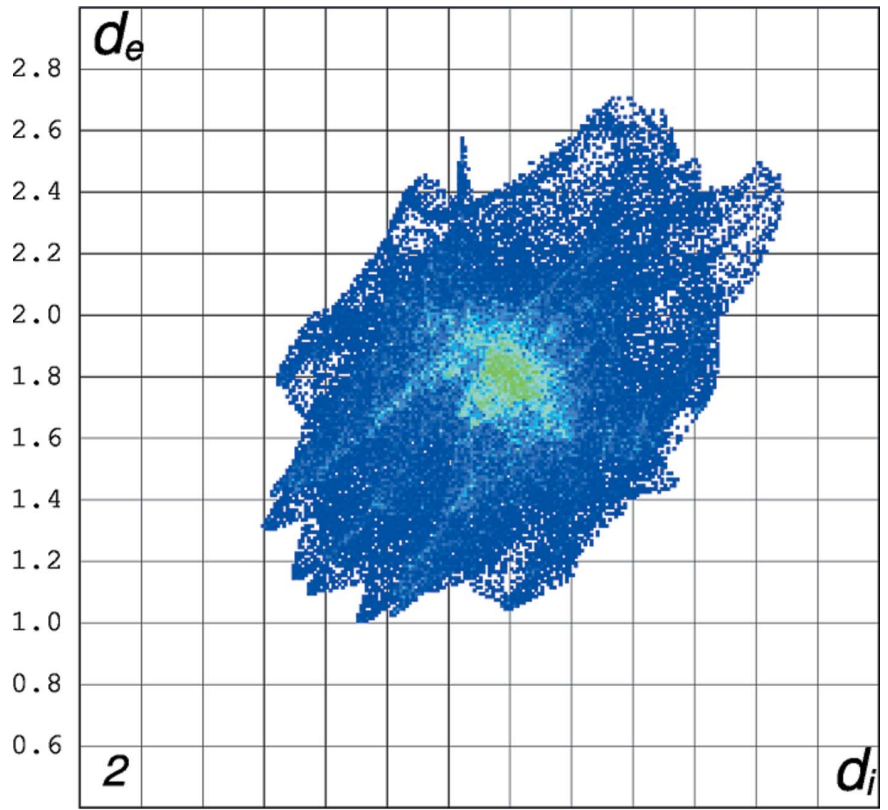

(Å) 0.60 .81 .01 .21 .41 .61 .82 .02 .22 .42 .62 .8

Figure 6

The FP plot for $1 \_P 2_{1} / \boldsymbol{n}$; the light-blue area in the middle of the FP plot is due to C $\cdots$ C contacts ( $7.1 \%$ of the area). The FP plot shows three sets of spikes pointing to southwest due to weak $\mathrm{C} \cdots \mathrm{H}$ contacts: the outer sharper ones are due to the $\mathrm{H} \cdot \mathrm{N}$ contacts that involves the N(thiazole) $\cdots \mathrm{H} 8-\mathrm{C} 8$ (chromone) interaction followed by the spikes corresponding to $\mathrm{O} \cdots \mathrm{H}$ contacts that englobe the $\mathrm{O} 4 \cdots \mathrm{H} 2$ _C 2 contacts and the inner one is due to close $\mathrm{S} \cdot \mathrm{H}$ contacts 
Table 5

Percentages for the most relevant atom-atom contacts for the studied compounds.

\begin{tabular}{|c|c|c|c|c|c|c|}
\hline Compound & $\mathrm{H} \cdots \mathrm{H}$ & $\mathrm{H} \cdots \mathrm{O} / \mathrm{O} \cdots \mathrm{H}$ & $\mathrm{H} \cdots \mathrm{N} / \mathrm{N} \cdots \mathrm{H}$ & $\mathrm{H} \cdots \mathrm{S} / \mathrm{S} \cdots \mathrm{H}$ & $\mathrm{H} \cdots \mathrm{C} / \mathrm{C} \cdots \mathrm{H}$ & $\mathrm{C} \cdots \mathrm{C}$ \\
\hline $1 \_P 2_{1} / n$ & 31.8 & 19.0 & 8.7 & 6.3 & 15.2 & 7.1 \\
\hline $1 \_P 2_{1} / c$ & 29.6 & 19.1 & 8.6 & 7.7 & 17.6 & 5.2 \\
\hline $1 \_P 2_{1} / c$ & 34.6 & 13.2 & 6.6 & 7.1 & 18.4 & 5.2 \\
\hline
\end{tabular}

A small red spot pointing to this group appears in the Hirshfeld surface, Fig. 5, left.

In Fig. 5 right, the mapping of the molecular electrostatic potential (ESP) in the context of crystal packing is shown. As the Hirshfeld surface partitions of the crystal space give nonoverlapping volumes associated with each molecule these surfaces give a kind of 'electrostatic complementarity'. The molecular ESP for $\boldsymbol{P 2}_{\mathbf{1}} / \boldsymbol{n}$ reveals red regions of strongly negative electrostatic potential surrounding the two carbonyl regions and the azo region of the thiazole fragment. The blue region is electropositive and it is predominantly located in the
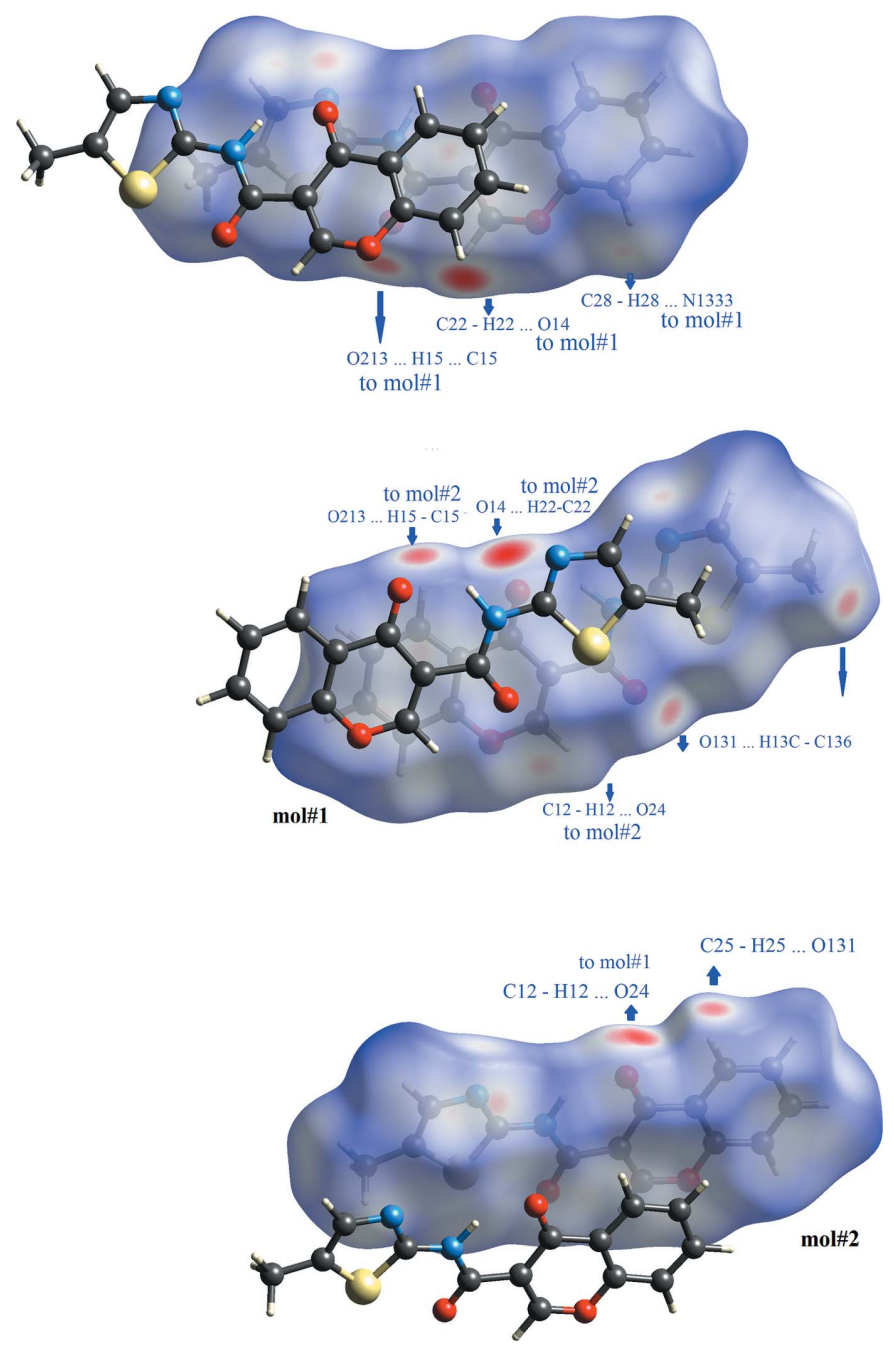

Figure 7

Views of the Hirshfeld surface mapped over $d_{\text {norm }}$ for $\mathbf{1} \_\boldsymbol{P 2} / \boldsymbol{c}$. The highlighted red spots on the top face of the surfaces indicate contact points with the atoms participating in the $\mathrm{C}-\mathrm{H} \cdots \mathrm{O} / \mathrm{N}$ intermolecular interactions. The red spot identified as a $\mathrm{C} 12-\mathrm{H} 12 \cdots \mathrm{O} 24$ contact in mol\#1 is located on the hidden face of the surface. chromone area near the $\mathrm{H} 2$ and $\mathrm{H} 8$ hydrogen atoms as well as in the methyl group of the thiazole. The remainder of the Hirshfeld surface is close to neutrality as seen by the grey regions. It is interesting to note that the mapped areas with electronegative potential corresponding to the areas covered by the atoms exhibiting negative natural atomic charges as computed by NBO (as seen in Fig. 2) with exception for the thiazole sulfur atom, which assumes a positive value by adiabatic gas-phase calculations, but gives a slightly negative electrostatic potential area at the Hirsfeld surface. The calculated partial charges show how the molecule would interact with an approaching proton and the molecular electrostatic potential is the potential energy that a proton would acquire at the surface, that is depending on the distance to the core nucleus of the molecule, suggesting that, in the crystal the sulfur surroundings experiences a deeper change in the eletrostatic potential gradient than that occurring in the remaining molecule, as compared with that of the adiabatic conditions.

Fig. 5 also highlights the electrostatic complementarity of the $\mathrm{C}-\mathrm{H} \cdots \mathrm{O} / \mathrm{N}$ contacts between the molecules. The electropositive (blue) patch above the chromone ring is in contact with the electronegative (red) regions around the carbonyl oxygen atom of the chromone $\mathrm{O} 4$ and the nitrogen atom of the thiazole ring N33 while the carbonyl oxygen atom of the amide $\mathrm{O} 3$ is pointing to the $\mathrm{H} 5$ hydrogen atom of the chromone ring. The electronegativity of this oxygen is lower than the electronegativity of the $\mathrm{O} 4$ of the chromone or the nitrogen atom of the thiazole N33. Thus the first shell molecular pairs are
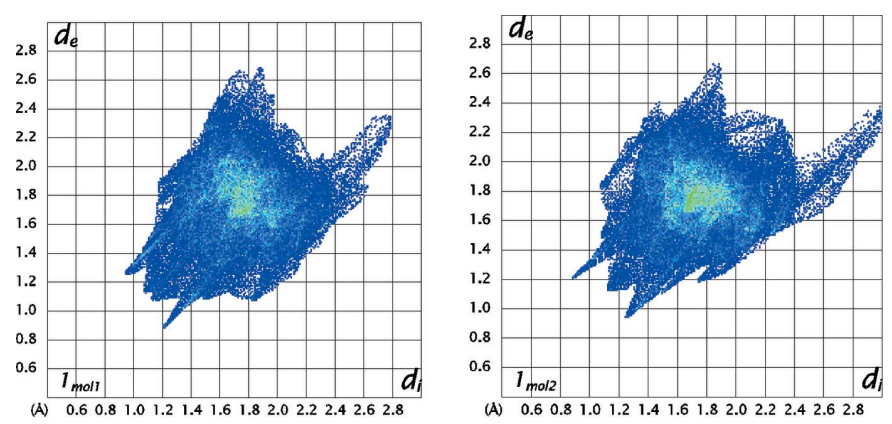

Figure 8

The FP plot for 1_P2 $/ \boldsymbol{c}$, mol\#1 on left and mol\#2 on right; The light-blue area in the middle of the FP plot at $d_{\mathrm{e}} / d_{\mathrm{i}} \sim 1.8 \AA$ shows a higher frequency of the pixels that are due to $\mathrm{C} \cdots \mathrm{C}$ contacts $(5.2 \%$ of the area for each molecule). The spikes pointing to southwest are due to weak $\mathrm{O} \cdots \mathrm{H}$ contacts. The asymmetric tails that both present are corresponding to $\mathrm{N} \cdots \mathrm{H}$ contacts in mol\#1. Their asymmetry is due to the fact that they connect two molecules that are not related by crystallographic symmetry. 

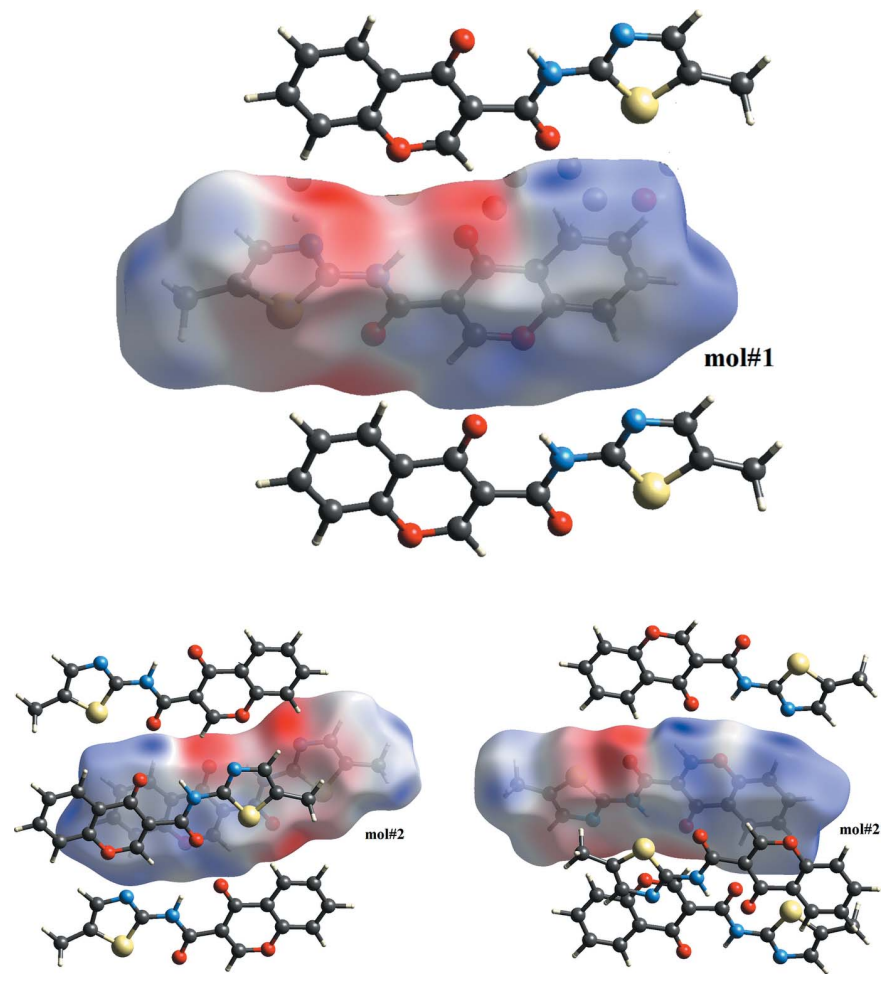

Figure 9

The electrostatic potential surfaces for $\mathbf{1} P \mathbf{P 2}_{1} / \boldsymbol{c}$, mol\#1 and mol\#2. The surfaces show the complementary electronegative (red) and electropositive areas (blue) with molecules of the first shell (ranging from -0.077 to 0.066 ). The ESP is electronegative in the vicinity of oxo oxygen atoms and of the nitrogen atom of the thiazole ring while it is electropositive in the areas that surrounds the $\mathrm{H} 2, \mathrm{H} 5$ and $\mathrm{H} 8$ hydrogen atoms of the chromone ring.

clearly associated with hydrogen bonds around the chromone ring periphery.

\section{$P 2_{1} / c$ (mol\#1 and \#2) polymorph}

The Hirshfeld surfaces printed over $d_{\text {norm }}$ for each molecule are shown in Fig. 7. Those surfaces show complementary red spots with each other; since mol\#1 is linked to mol\#2 and vice versa, they map pairs of dimers that connect the molecules in chains. Here, the hydrogen bonds that contribute to the linking of the mol\#1 with mol\#2 are the following: (i) the oxo oxygen atom of the chromone of mol\#1 acts as acceptor for the $\mathrm{H} 2$ hydrogen atom of the chromone of mol\#2 (O14 $\cdots \mathrm{H} 22-$ $\mathrm{C} 22)$ and vice versa (O24.-H12-C12); (ii) the carboxyl oxygen atom of the amide in mol\#1 links the hydrogen atom $\mathrm{H} 5$ of the chromone ring in mol\#2 (O13 - H25-C25) and vice versa $(\mathrm{O} 23 \cdots \mathrm{H} 15-\mathrm{C} 15)$; (iii) the nitrogen atom of the thiazole in mol\#1 acts as acceptor for $\mathrm{H} 8$ hydrogen atom of mol\#2

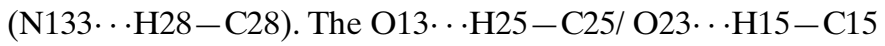
bond pair was not present in $1 \_P 2_{1} / \boldsymbol{n}$ polymorph while the remaining two were also observed. There is another pair of blue spots in the Hirshfeld surface of mol\#1that are complementary in shape and they refer to the O13 $\cdots \mathrm{H} 13 \mathrm{C}-\mathrm{C} 136$ contact.
The FP plots for polymorph $1 \_P 2_{1} / c$ (mol\#1 and \#2) are shown in Fig. 8. The FP plots highlight the differences in distribution of close contacts between mol\#1 and mol\#2. The asymmetric tails that are both present correspond to $\mathrm{N} \cdots \mathrm{H}$ contacts in mol\#1 and the sharp spikes are due to the $\mathrm{O} \cdots \mathrm{H}$ contacts. Their asymmetry is due to the fact that they connect two molecules that are not related by crystallographic symmetry. The sharper line in mol\#1 FP that ends at about $(1.2 ; 0.9)$ corresponds to $\mathrm{O} \cdots \mathrm{H}$ contacts that mol\#1 makes with mol\#2. Those contacts relate to the ones given by the sharper line that ends at about $(0.9 ; 1.2)$ in the FP of mol\#2. It is noticeable the differences in sharpness of the $\mathrm{O} \cdots \mathrm{H}$ spikes presented in the FP plots $\mathbf{1} \_\boldsymbol{P} \mathbf{2}_{\mathbf{1}} / \boldsymbol{c}$ when compared with the FP plot of the polymorph $1 \_P 2_{1} / \boldsymbol{n}$ showing that in $1 \_P 2_{1} / c$ the $\mathrm{O} \cdots \mathrm{H}$ contacts are more directional and shorter. Those plots also reflect the differences regarding the close contacts between molecules: the light blue/green area in the middle of the FP plot in 1_P2 $/ \boldsymbol{n}$ is less spread out and more intense that the area presented in the FP plot of $1 \_P 2_{1} / c$ suggesting that the C. . C close contacts are more relevant in first polymorph.

Fig. 9 depicts the Hirshfeld surfaces mapped over the electrostatic potential and once again the complementary electrostatic nature of the contacts are clear from the figure. The ESP is electronegative in the vicinity of oxo oxygen atoms and of the nitrogen atom of the thiazole ring while it is electropositive in the areas that surrounds the $\mathrm{H} 2, \mathrm{H} 5$ and $\mathrm{H} 8$ hydrogen atoms of the chromone ring.

\section{Synthesis and crystallization}

Chromone-3-carboxylic acid, phosphorus(V) oxychloride, dimethylformamide (DMF) and 5-methylthiazol-2-amine were purchased from Sigma-Aldrich Química S.A. (Sintra, Portugal). All other reagents and solvents were pro analysis grade and used without additional purification. Thin-layer chromatography (TLC) was carried out on precoated silica gel 60 F254 (Merck) with layer thickness of $0.2 \mathrm{~mm}$ and ethyl acetate/petroleum ether as the mobile phase. The spots were visualized under UV detection (254 and $366 \mathrm{~nm}$ ) and iodine vapour. Flash chromatography was performed using silica gel $600.2-0.5$ or $0.040-0.063 \mathrm{~mm}$ (Carlo Erba Reagents).

Synthesis of $\mathbf{N}$-(5-methylthiazol-2-yl)-4-oxo-4H-chromene-3-carboxamide

To a solution of chromone-3-carboxylic acid (500 mg, $2.6 \mathrm{mmol})$ in DMF (4 ml) $\mathrm{POCl}_{3}(241 \mathrm{ml}, 2.6 \mathrm{mmol})$ was added. The mixture was stirred at room temperature for $30 \mathrm{~min}$, with the formation in situ of the corresponding acyl chloride. Then, the 5-methylthiazol-2-amine was added. After $12 \mathrm{~h}$, the mixture was diluted with dichloromethane $(20 \mathrm{ml})$, washed with $\mathrm{H}_{2} \mathrm{O}(2 \times 10 \mathrm{ml})$ and with saturated $\mathrm{NaHCO}_{3}$ solution $(2 \times 10 \mathrm{ml})$. The organic phase was dried with $\mathrm{Na}_{2} \mathrm{SO}_{4}$, filtered and concentrated under reduced pressure. The residue was purified by flash chromatography $(20 \%$ ethyl acetate/petroleum ether) and $N$-(5-methylthiazol-2-yl)-4-oxo$4 H$-chromene-3-carboxamide was obtained as a solid $(153 \mathrm{mg}$, $20 \%$ ). ${ }^{1} \mathrm{H}$ NMR (400 MHz, $\left.\mathrm{CDCl}_{3}\right) \delta 12.43(\mathrm{NH}, s, 1 \mathrm{H}), 9.05$ $(\mathrm{H} 3, s, 1 \mathrm{H}), 8.35(\mathrm{H} 5, d d, J=8.0,1.5 \mathrm{~Hz}, 1 \mathrm{H}), 7.80(\mathrm{H} 7, d d d, J=$ 
Table 6

Experimental details.

\begin{tabular}{|c|c|c|}
\hline & $P 2_{1} / n$ & $P 2_{1} / c$ \\
\hline Chemical formula & $\mathrm{C}_{14} \mathrm{H}_{10} \mathrm{~N}_{2} \mathrm{O}_{3} \mathrm{~S}$ & $\mathrm{C}_{14} \mathrm{H}_{10} \mathrm{~N}_{2} \mathrm{O}_{3} \mathrm{~S}$ \\
\hline$M_{\mathrm{r}}$ & 286.30 & 286.30 \\
\hline Temperature (K) & 100 & 100 \\
\hline$a, b, c(\AA)$ & $4.8722(4), 12.0436(10), 21.9803(16)$ & $7.4646(5), 30.626(2), 11.0869(8)$ \\
\hline$\beta\left(^{\circ}\right)$ & $96.353(8)$ & $93.232(2)$ \\
\hline$V\left(\AA^{3}\right)$ & $1281.86(18)$ & $2530.6(3)$ \\
\hline$\mu\left(\mathrm{mm}^{-1}\right)$ & 0.26 & 0.26 \\
\hline Crystal size (mm) & $0.28 \times 0.03 \times 0.02$ & $0.06 \times 0.06 \times 0.01$ \\
\hline \multicolumn{3}{|l|}{ Data collection } \\
\hline Diffractometer & Rigaku Saturn724+ & Rigaku Saturn724+ \\
\hline Absorption correction & $\begin{array}{l}\text { Multi-scan (CrystalClear-SM Expert; Rigaku, } \\
\text { 2012) }\end{array}$ & $\begin{array}{l}\text { Multi-scan (CrystalClear-SM Expert; Rigaku, } \\
\text { 2012) }\end{array}$ \\
\hline$(\sin \theta / \lambda)_{\max }\left(\AA^{-1}\right)$ & 0.651 & 0.650 \\
\hline \multicolumn{3}{|l|}{ Refinement } \\
\hline$R\left[F^{2}>2 \sigma\left(F^{2}\right)\right], w R\left(F^{2}\right), S$ & $0.097,0.223,1.13$ & $0.060,0.153,1.08$ \\
\hline No. of reflections & 2944 & 5716 \\
\hline No. of parameters & 182 & 371 \\
\hline $\mathrm{H}$-atom treatment & $\mathrm{H}$-atom parameters constrained & $\begin{array}{l}\mathrm{H} \text { atoms treated by a mixture of independent } \\
\text { and constrained refinement }\end{array}$ \\
\hline$\Delta \rho_{\max }, \Delta \rho_{\min }\left(\mathrm{e} \AA^{-3}\right)$ & $1.15,-0.37$ & $0.46,-0.37$ \\
\hline
\end{tabular}

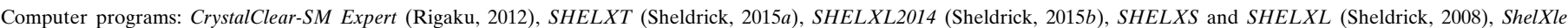
(Hübschle et al., 2011), OSCAIL (McArdle et al., 2004), Mercury (Macrae et al., 2006) and PLATON (Spek, 2009).

8.7, 7.2, $1.5 \mathrm{~Hz}, 1 \mathrm{H}), 7.59(\mathrm{H} 8, d d, J=8.7,1.6 \mathrm{~Hz}, 1 \mathrm{H}), 7.54$ $(\mathrm{H} 6, d d d, J=8.0,7.2,1.0 \mathrm{~Hz}, 1 \mathrm{H}), 7.17(\mathrm{H} 34, q, J=1.2 \mathrm{~Hz}, 1 \mathrm{H})$, $2.43\left(\mathrm{CH}_{3}, d, J=1.2 \mathrm{~Hz}, 3 \mathrm{H}\right) \cdot{ }^{13} \mathrm{C} \mathrm{NMR}\left(101 \mathrm{MHz}, \mathrm{CDCl}_{3}\right) \delta$ 176.7 C4), 163.0 (C2), 160.3 (C31), 156.2 (C32), 155.5 (C8a), 135.4 (C7), 135.2 (C34), 128.4 (C35), 126.9 (C5), 126.7 (C6), 124.1 (C4a, C), $118.6(\mathrm{C} 8), 114.6(\mathrm{C} 3), 11.7\left(\mathrm{CH}_{3}\right)$. EM/IE $m / z$ : $287\left(\mathrm{M}^{+}+1,30\right), 286.0\left(M^{+}, 91\right), 174(30), 173(100$

\section{Refinement}

Crystal data, data collection and structure refinement details are summarized in Table 5. Crystals of the title compound with different morphologies were found in the crystallized sample. In each case several attempts were made at obtaining crystals which gave the best available data set for both types of morphology; 1_P2 $/ \boldsymbol{n}$ : the crystals were long needles, which could not be cut, as they shattered. The needle used showed slight streaking on the images. The high angle data were very weak, with significant drop in intensity from the lower angle reflections. These facts probably explain the relatively high $R$ factor in the refinement of this compound. The following reflections were omitted from the refinement: 002 and 011 that were obstructed by beamstop and 0101,011 1, 0121,0 113 as recommend by the PLAT934_ALERT_3_B because $\left(I_{\text {obs }}-I_{\text {calc }}\right) / \Sigma w>1$.
1_P2 $/ c$ : the crystals were prismatic in habit. The following reflections were omitted from the refinement: 011 obstructed by beamstop, $\overline{8} 18, \overline{8} 0 \quad 6$ as recommend by the PLAT934_ALERT_3_B because $\left(I_{\text {obs }}-I_{\text {calc }}\right) / \Sigma w>10$.

The hydrogen atoms attached to the carboxamide $\mathrm{N}$ atom in

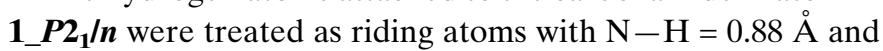
$U_{\text {iso }}(\mathrm{H})=1.2 U_{\text {eq }}(\mathrm{N})$ while those in $\mathbf{1} \_\boldsymbol{P} 2_{1} / c$ were refined. All other $\mathrm{H}$ atoms were treated as riding atoms with $\mathrm{C}-$ $\mathrm{H}($ aromatic $)=0.95 \AA \mathrm{C}-\mathrm{H}($ methyl $)=0.98 \AA$ with $U_{\text {iso }}(\mathrm{H})=$ $1.5 U_{\mathrm{eq}}(\mathrm{C})$. The positions of the amino and methyl hydrogenatom positions were checked on a final difference map.

\section{Acknowledgements}

The authors thank the National Crystallographic Service, University of Southampton for the data collection and for their help and advice (Coles \& Gale, 2012).

\section{Funding information}

This work was supported by the Portuguese Foundation for Science and Technology (FCT) (PEst-C/QUI/UI0081/2013 and UID/Multi/04546/2013 to FC), (SFRH/BPD/74491/2010 grants are supported by FCT). 


\section{References}

Cagide, F., Borges, F., Gomes, L. R. \& Low, J. N. (2015). J. Mol. Struct. 1089, 206-215.

Coles, S. J. \& Gale, P. A. (2012). Chem. Sci. 3, 683-689.

Gaspar, A., Matos, M. J., Garrido, M., Uriarte, E. \& Borges, F. (2014). Chem. Rev. 114, 4960-4992.

Gaspar, A., Reis, J., Kachler, S., Paoletta, S., Uriarte, E., Klotz, K. N., Moro, S. \& Borges, F. (2012a). Biochem. Pharmacol. 84, 21-29.

Gaspar, A., Reis, J., Matos, M. J., Uriarte, E. \& Borges, F. (2012b). Eur. J. Med. Chem. 54, 914-918.

Gomes, L. R., Low, J. N., Cagide, F. \& Borges, F. (2015b). Acta Cryst. E71, 88-93.

Gomes, L. R., Low, J. N., Cagide, F., Gaspar, A. \& Borges, F. (2015a). Acta Cryst. E71, 1270-1277.

Hübschle, C. B., Sheldrick, G. M. \& Dittrich, B. (2011). J. Appl. Cryst. 44, 1281-1284.

Jung, K., Kim, S., Gao, Z., Gross, A. S., Melman, N., Jacobson, K. A. \& Kim, Y. (2004). Bioorg. Med. Chem. 12, 613-623.
Macrae, C. F., Edgington, P. R., McCabe, P., Pidcock, E., Shields, G. P., Taylor, R., Towler, M. \& van de Streek, J. (2006). J. Appl. Cryst. 39, 453-457.

McArdle, P., Gilligan, K., Cunningham, D., Dark, R. \& Mahon, M. (2004). CrystEngComm, 6, 303-309.

Rigaku (2012). CrystalClear-SM Expert. Rigaku Corporation, Tokyo, Japan.

Rohl, A. L., Moret, M., Kaminsky, W., Claborn, K., McKinnon, J. J. \& Kahr, B. (2008). Cryst. Growth Des. 8, 4517-4525.

Sharma, R. N., Xavier, F. P., Vasu, K. K., Chaturvedi, S. C. \& Pancholi, S. S. (2009). J. Enzyme Inhib. Med. Chem. 24, 890-897.

Sheldrick, G. M. (2008). Acta Cryst. A64, 112-122.

Sheldrick, G. M. (2015a). Acta Cryst. A71, 3-8.

Sheldrick, G. M. (2015b). Acta Cryst. C71, 3-8.

Siddiqui, N., Arshad, M. F., Ahsan, W. S. \& Alam, M. S. (2009). Int. J. Pharm. Sci. Drug Res. 1, 136-143.

Souza, M. V. N. de (2005). J. Sulfur Chem. 26, 429-449.

Spek, A. L. (2009). Acta Cryst. D65, 148-155.

Wolff, S. K., Grimwood, D. J., McKinnon, J. J., Turner, M. J., Jayatilaka, D. \& Spackman, M. A. (2012). Crystal Explorer. The University of Western Australia. 


\section{supporting information}

Acta Cryst. (2017). E73, 1154-1161 [https://doi.org/10.1107/S2056989017009902]

Polymorphism in the structure of $\mathrm{N}$-(5-methylthiazol-2-yl)-4-oxo-4Hchromene-3-carboxamide

\section{Ligia R. Gomes, John Nicolson Low, Fernando Cagide and Fernanda Borges}

Computing details

For both structures, data collection: CrystalClear-SM Expert (Rigaku, 2012); cell refinement: CrystalClear-SM Expert (Rigaku, 2012); data reduction: CrystalClear-SM Expert (Rigaku, 2012). Program(s) used to solve structure: SHELXT (Sheldrick, 2015a) for 1_P2 1 _n; SHELXS (Sheldrick, 2008) for 1_P2 1 _c. Program(s) used to refine structure: OSCAIL (McArdle et al., 2004), ShelXle (Hübschle et al., 2011) and SHELXL2014 (Sheldrick, 2015b) for 1_P2 1 _n; OSCAIL (McArdle et al., 2004), ShelXle (Hübschle et al., 2011) SHELXL (Sheldrick, 2008) for 1_P2 1 _c. For both structures, molecular graphics: Mercury (Macrae et al., 2006). Software used to prepare material for publication: OSCAIL (McArdle et al., 2004), SHELXL2014 (Sheldrick, 2015b) and PLATON (Spek, 2009) for 1_P2 1 _n; OSCAIL (McArdle et al., 2004), SHELXL (Sheldrick, 2008) for 1_P2 1 _c.

N-(5-Methylthiazol-2-yl)-4-oxo-4H-chromene-3-carboxamide (1_P2 1 _n)

\section{Crystal data}

$\mathrm{C}_{14} \mathrm{H}_{10} \mathrm{~N}_{2} \mathrm{O}_{3} \mathrm{~S}$

$M_{r}=286.30$

Monoclinic, $P 2{ }_{1} / n$

$a=4.8722(4) \AA$

$b=12.0436(10) \AA$

$c=21.9803(16) \AA$

$\beta=96.353(8)^{\circ}$

$V=1281.86(18) \AA^{3}$

$Z=4$

\section{Data collection}

Rigaku Saturn724+ diffractometer

Radiation source: Enhance (Mo) X-ray Source

Graphite monochromator

profile data from $\omega$-scans

Absorption correction: multi-scan

(CrystalClear-SM Expert; Rigaku, 2012)

$T_{\min }=0.814, T_{\max }=1.000$

Refinement

Refinement on $F^{2}$

Least-squares matrix: full

$R\left[F^{2}>2 \sigma\left(F^{2}\right)\right]=0.097$

$w R\left(F^{2}\right)=0.223$
$F(000)=592$

$D_{\mathrm{x}}=1.484 \mathrm{Mg} \mathrm{m}^{-3}$

Mo $K \alpha$ radiation, $\lambda=0.71073 \AA$

Cell parameters from 3369 reflections

$\theta=2.5-27.5^{\circ}$

$\mu=0.26 \mathrm{~mm}^{-1}$

$T=100 \mathrm{~K}$

Needle, yellow

$0.28 \times 0.03 \times 0.02 \mathrm{~mm}$

13600 measured reflections

2944 independent reflections

1980 reflections with $I>2 \sigma(I)$

$R_{\text {int }}=0.084$

$\theta_{\max }=27.5^{\circ}, \theta_{\min }=2.5^{\circ}$

$h=-6 \rightarrow 6$

$k=-15 \rightarrow 15$

$l=-28 \rightarrow 28$

$S=1.13$

2944 reflections

182 parameters

0 restraints 
Hydrogen site location: inferred from neighbouring sites

H-atom parameters constrained

$$
\begin{aligned}
& w=1 /\left[\sigma^{2}\left(F_{\mathrm{o}}^{2}\right)+(0.0714 P)^{2}+3.9146 P\right] \\
& \text { where } P=\left(F_{\mathrm{o}}^{2}+2 F_{\mathrm{c}}^{2}\right) / 3 \\
& (\Delta / \sigma)_{\max }=0.001 \\
& \Delta \rho_{\max }=1.15 \mathrm{e} \AA^{-3} \\
& \Delta \rho_{\min }=-0.37 \mathrm{e} \AA^{-3}
\end{aligned}
$$

\section{Special details}

Geometry. All esds (except the esd in the dihedral angle between two 1.s. planes) are estimated using the full covariance

\begin{tabular}{|c|c|c|c|c|}
\hline & $x$ & $y$ & $z$ & $U_{\text {iso }} * / U_{\text {eq }}$ \\
\hline $\mathrm{S} 31$ & $0.9829(3)$ & 0.89007 (11) & $0.43688(5)$ & 0.0282 \\
\hline $\mathrm{O} 1$ & $-0.0148(6)$ & $1.0107(2)$ & $0.21301(14)$ & $0.0251(7)$ \\
\hline $\mathrm{O} 3$ & $0.6328(7)$ & $0.9809(3)$ & $0.34453(14)$ & $0.0297(8)$ \\
\hline O4 & $0.1136(6)$ & 0.7088 & $0.29518(14)$ & $0.0252(7)$ \\
\hline N3 & $0.5557(8)$ & $0.7992(3)$ & $0.36084(16)$ & $0.0245(9)$ \\
\hline H3 & 0.4531 & 0.7413 & 0.3489 & $0.029 *$ \\
\hline N33 & $0.8145(9)$ & $0.6867(4)$ & $0.43227(18)$ & $0.0323(10)$ \\
\hline $\mathrm{C} 2$ & $0.1942(10)$ & $0.9927(4)$ & $0.2566(2)$ & $0.0245(10)$ \\
\hline $\mathrm{H} 2$ & 0.3134 & 1.0535 & 0.2678 & $0.029 *$ \\
\hline $\mathrm{C} 3$ & $0.2503(9)$ & $0.8961(4)$ & $0.28596(19)$ & $0.0221(10)$ \\
\hline $\mathrm{C} 4$ & $0.0784(9)$ & 0.7999 (4) & 0.27017 (19) & $0.0211(9)$ \\
\hline $\mathrm{C} 5$ & $-0.3234(10)$ & $0.7340(4)$ & 0.1989 (2) & $0.0253(10)$ \\
\hline H5 & -0.2989 & 0.6614 & 0.2154 & $0.030 *$ \\
\hline $\mathrm{C} 4 \mathrm{~A}$ & $-0.1452(9)$ & $0.8189(4)$ & 0.22095 (19) & $0.0213(10)$ \\
\hline C6 & $-0.5338(10)$ & $0.7543(4)$ & $0.1535(2)$ & $0.0274(11)$ \\
\hline H6 & -0.6547 & 0.6959 & 0.1389 & $0.033^{*}$ \\
\hline $\mathrm{C} 7$ & $-0.5705(10)$ & $0.8606(4)$ & 0.1288 & $0.0272(11)$ \\
\hline H7 & -0.7176 & 0.8742 & 0.0976 & $0.033^{*}$ \\
\hline $\mathrm{C} 8$ & $-0.3976(10)$ & $0.9455(4)$ & 0.1489 & $0.0264(10)$ \\
\hline H8 & -0.4214 & 1.0179 & 0.1320 & $0.032 *$ \\
\hline C8A & $-0.1864(10)$ & $0.9224(4)$ & $0.1947(2)$ & $0.0237(10)$ \\
\hline C31 & $0.4964(9)$ & $0.8976(4)$ & $0.33283(19)$ & $0.0224(10)$ \\
\hline $\mathrm{C} 32$ & $0.7694(10)$ & $0.7843(4)$ & $0.4073(2)$ & $0.0283(11)$ \\
\hline $\mathrm{C} 34$ & $1.0346(11)$ & $0.6953(5)$ & $0.4779(2)$ & $0.0357(13)$ \\
\hline H34 & 1.1015 & 0.6326 & 0.5012 & $0.043 *$ \\
\hline $\mathrm{C} 35$ & $1.1488(10)$ & $0.7959(4)$ & $0.4877(2)$ & $0.0304(11)$ \\
\hline C351 & $1.3848(10)$ & $0.8291(5)$ & $0.5342(2)$ & 0.0368 (13) \\
\hline $\mathrm{H} 35 \mathrm{~A}$ & 1.4522 & 0.7638 & 0.5579 & $0.055^{*}$ \\
\hline H35B & 1.3213 & 0.8851 & 0.5618 & $0.055^{*}$ \\
\hline $\mathrm{H} 35 \mathrm{C}$ & 1.5347 & 0.8601 & 0.5131 & $0.055^{*}$ \\
\hline
\end{tabular}
matrix. The cell esds are taken into account individually in the estimation of esds in distances, angles and torsion angles; correlations between esds in cell parameters are only used when they are defined by crystal symmetry. An approximate (isotropic) treatment of cell esds is used for estimating esds involving l.s. planes.

Fractional atomic coordinates and isotropic or equivalent isotropic displacement parameters $\left(\AA^{2}\right)$ 
Atomic displacement parameters $\left(\AA^{2}\right)$

\begin{tabular}{lllllll}
\hline & $U^{11}$ & $U^{22}$ & $U^{33}$ & $U^{12}$ & $U^{13}$ & $U^{23}$ \\
\hline S31 & $0.0245(7)$ & $0.0323(7)$ & $0.0281(6)$ & $0.0009(6)$ & $0.0043(5)$ & $-0.0015(5)$ \\
O1 & $0.0252(19)$ & $0.0153(16)$ & $0.0340(17)$ & $-0.0006(14)$ & $-0.0002(14)$ & $0.0028(13)$ \\
O3 & $0.030(2)$ & $0.0216(18)$ & $0.0369(18)$ & $-0.0055(15)$ & $0.0001(14)$ & $-0.0001(14)$ \\
O4 & $0.0245(19)$ & $0.0164(16)$ & $0.0349(17)$ & $0.0041(14)$ & $0.0040(14)$ & $0.0008(13)$ \\
N3 & $0.024(2)$ & $0.020(2)$ & $0.0289(19)$ & $0.0002(17)$ & $0.0021(16)$ & $-0.0030(15)$ \\
N33 & $0.035(3)$ & $0.029(2)$ & $0.032(2)$ & $0.006(2)$ & $-0.0008(18)$ & $-0.0040(17)$ \\
C2 & $0.024(3)$ & $0.017(2)$ & $0.034(2)$ & $-0.002(2)$ & $0.007(2)$ & $-0.0012(18)$ \\
C3 & $0.023(3)$ & $0.017(2)$ & $0.028(2)$ & $0.0020(19)$ & $0.0098(18)$ & $0.0005(17)$ \\
C4 & $0.022(2)$ & $0.015(2)$ & $0.028(2)$ & $0.0033(19)$ & $0.0093(18)$ & $-0.0021(17)$ \\
C5 & $0.026(3)$ & $0.020(2)$ & $0.031(2)$ & $0.001(2)$ & $0.009(2)$ & $0.0017(18)$ \\
C4A & $0.023(3)$ & $0.015(2)$ & $0.028(2)$ & $-0.0045(19)$ & $0.0098(19)$ & $-0.0027(17)$ \\
C6 & $0.025(3)$ & $0.025(3)$ & $0.033(2)$ & $-0.003(2)$ & $0.005(2)$ & $-0.0058(19)$ \\
C7 & $0.027(3)$ & $0.027(3)$ & $0.028(2)$ & $0.001(2)$ & $0.003(2)$ & $0.0012(18)$ \\
C8 & $0.026(3)$ & $0.021(2)$ & $0.033(2)$ & $0.005(2)$ & $0.004(2)$ & $0.0036(18)$ \\
C8A & $0.024(3)$ & $0.017(2)$ & $0.032(2)$ & $-0.0016(19)$ & $0.010(2)$ & $-0.0032(18)$ \\
C31 & $0.023(3)$ & $0.017(2)$ & $0.028(2)$ & $0.000(2)$ & $0.0077(19)$ & $-0.0023(17)$ \\
C32 & $0.033(3)$ & $0.026(3)$ & $0.027(2)$ & $0.004(2)$ & $0.008(2)$ & $-0.0043(18)$ \\
C34 & $0.037(3)$ & $0.042(3)$ & $0.026(2)$ & $0.020(3)$ & $0.000(2)$ & $-0.002(2)$ \\
C35 & $0.025(3)$ & $0.039(3)$ & $0.028(2)$ & $0.007(2)$ & $0.006(2)$ & $-0.004(2)$ \\
C351 & $0.027(3)$ & $0.048(3)$ & $0.034(3)$ & $0.004(3)$ & $0.001(2)$ & $-0.005(2)$ \\
& & & & & & \\
\hline
\end{tabular}

Geometric parameters $\left(A,{ }^{\circ}\right)$

\begin{tabular}{llll}
\hline $\mathrm{S} 31-\mathrm{C} 32$ & $1.726(5)$ & $\mathrm{C} 5-\mathrm{C} 6$ & $1.371(7)$ \\
$\mathrm{S} 31-\mathrm{C} 35$ & $1.728(5)$ & $\mathrm{C} 5-\mathrm{C} 4 \mathrm{~A}$ & $1.393(6)$ \\
$\mathrm{O} 1-\mathrm{C} 2$ & $1.336(6)$ & $\mathrm{C} 5-\mathrm{H} 5$ & 0.9500 \\
$\mathrm{O} 1-\mathrm{C} 8 \mathrm{~A}$ & $1.384(5)$ & $\mathrm{C} 4 \mathrm{~A}-\mathrm{C} 8 \mathrm{~A}$ & $1.379(6)$ \\
$\mathrm{O} 3-\mathrm{C} 31$ & $1.215(5)$ & $\mathrm{C} 6-\mathrm{C} 7$ & $1.394(7)$ \\
$\mathrm{O} 4-\mathrm{C} 4$ & $1.231(5)$ & $\mathrm{C} 6-\mathrm{H} 6$ & 0.9500 \\
$\mathrm{~N} 3-\mathrm{C} 31$ & $1.353(6)$ & $\mathrm{C} 7-\mathrm{C} 8$ & $1.367(7)$ \\
$\mathrm{N} 3-\mathrm{C} 32$ & $1.387(6)$ & $\mathrm{C} 7-\mathrm{H} 7$ & 0.9500 \\
$\mathrm{~N} 3-\mathrm{H} 3$ & 0.8800 & $\mathrm{C} 8-\mathrm{C} 8 \mathrm{~A}$ & $1.387(7)$ \\
$\mathrm{N} 33-\mathrm{C} 32$ & $1.306(6)$ & $\mathrm{C} 8-\mathrm{H} 8$ & 0.9500 \\
$\mathrm{~N} 33-\mathrm{C} 34$ & $1.388(6)$ & $\mathrm{C} 34-\mathrm{C} 35$ & $1.341(7)$ \\
$\mathrm{C} 2-\mathrm{C} 3$ & $1.344(6)$ & $\mathrm{C} 34-\mathrm{H} 34$ & 0.9500 \\
$\mathrm{C} 2-\mathrm{H} 2$ & 0.9500 & $\mathrm{C} 35-\mathrm{C} 351$ & $1.506(7)$ \\
$\mathrm{C} 3-\mathrm{C} 4$ & $1.449(6)$ & $\mathrm{C} 351-\mathrm{H} 35 \mathrm{~A}$ & 0.9800 \\
$\mathrm{C} 3-\mathrm{C} 31$ & $1.492(7)$ & $\mathrm{C} 351-\mathrm{H} 35 \mathrm{~B}$ & 0.9800 \\
$\mathrm{C} 4-\mathrm{C} 4 \mathrm{~A}$ & $1.466(6)$ & $\mathrm{C} 351-\mathrm{H} 35 \mathrm{C}$ & 0.9800 \\
& & & 119.5 \\
$\mathrm{C} 32-\mathrm{S} 31-\mathrm{C} 35$ & $88.8(2)$ & $\mathrm{C} 6-\mathrm{C} 7-\mathrm{H} 7$ & $117.8(4)$ \\
$\mathrm{C} 2-\mathrm{O} 1-\mathrm{C} 8 \mathrm{~A}$ & $118.1(4)$ & $\mathrm{C} 7-\mathrm{C} 8-\mathrm{C} 8 \mathrm{~A}$ & 121.1 \\
$\mathrm{C} 31-\mathrm{N} 3-\mathrm{C} 32$ & $123.6(4)$ & $\mathrm{C} 7-\mathrm{C} 8-\mathrm{H} 8$ & 121.1 \\
$\mathrm{C} 31-\mathrm{N} 3-\mathrm{H} 3$ & 118.2 & $\mathrm{C} 8 \mathrm{~A}-\mathrm{C} 8-\mathrm{H} 8$ & $121.2(4)$ \\
$\mathrm{C} 32-\mathrm{N} 3-\mathrm{H} 3$ & 118.2 & $\mathrm{C} 4 \mathrm{~A}-\mathrm{C} 8 \mathrm{~A}-\mathrm{O} 1$ &
\end{tabular}




\begin{tabular}{|c|c|}
\hline $\mathrm{C} 32-\mathrm{N} 33-\mathrm{C} 34$ & $108.4(4)$ \\
\hline $\mathrm{O} 1-\mathrm{C} 2-\mathrm{C} 3$ & $125.7(4)$ \\
\hline $\mathrm{O} 1-\mathrm{C} 2-\mathrm{H} 2$ & 117.2 \\
\hline $\mathrm{C} 3-\mathrm{C} 2-\mathrm{H} 2$ & 117.2 \\
\hline $\mathrm{C} 2-\mathrm{C} 3-\mathrm{C} 4$ & $119.7(4)$ \\
\hline $\mathrm{C} 2-\mathrm{C} 3-\mathrm{C} 31$ & $115.2(4)$ \\
\hline $\mathrm{C} 4-\mathrm{C} 3-\mathrm{C} 31$ & $125.0(4)$ \\
\hline $\mathrm{O} 4-\mathrm{C} 4-\mathrm{C} 3$ & $123.9(4)$ \\
\hline $\mathrm{O} 4-\mathrm{C} 4-\mathrm{C} 4 \mathrm{~A}$ & $121.6(4)$ \\
\hline $\mathrm{C} 3-\mathrm{C} 4-\mathrm{C} 4 \mathrm{~A}$ & $114.5(4)$ \\
\hline $\mathrm{C} 6-\mathrm{C} 5-\mathrm{C} 4 \mathrm{~A}$ & $120.7(4)$ \\
\hline $\mathrm{C} 6-\mathrm{C} 5-\mathrm{H} 5$ & 119.7 \\
\hline $\mathrm{C} 4 \mathrm{~A}-\mathrm{C} 5-\mathrm{H} 5$ & 119.7 \\
\hline $\mathrm{C} 8 \mathrm{~A}-\mathrm{C} 4 \mathrm{~A}-\mathrm{C} 5$ & $117.5(4)$ \\
\hline $\mathrm{C} 8 \mathrm{~A}-\mathrm{C} 4 \mathrm{~A}-\mathrm{C} 4$ & $120.7(4)$ \\
\hline $\mathrm{C} 5-\mathrm{C} 4 \mathrm{~A}-\mathrm{C} 4$ & $121.8(4)$ \\
\hline $\mathrm{C} 5-\mathrm{C} 6-\mathrm{C} 7$ & $120.0(5)$ \\
\hline $\mathrm{C} 5-\mathrm{C} 6-\mathrm{H} 6$ & 120.0 \\
\hline $\mathrm{C} 7-\mathrm{C} 6-\mathrm{H} 6$ & 120.0 \\
\hline $\mathrm{C} 8-\mathrm{C} 7-\mathrm{C} 6$ & $120.9(5)$ \\
\hline $\mathrm{C} 8-\mathrm{C} 7-\mathrm{H} 7$ & 119.5 \\
\hline $\mathrm{C} 8 \mathrm{~A}-\mathrm{O} 1-\mathrm{C} 2-\mathrm{C} 3$ & $-1.8(6)$ \\
\hline $\mathrm{O} 1-\mathrm{C} 2-\mathrm{C} 3-\mathrm{C} 4$ & $0.9(7)$ \\
\hline $\mathrm{O} 1-\mathrm{C} 2-\mathrm{C} 3-\mathrm{C} 31$ & $179.9(4)$ \\
\hline $\mathrm{C} 2-\mathrm{C} 3-\mathrm{C} 4-\mathrm{O} 4$ & $-179.2(4)$ \\
\hline $\mathrm{C} 31-\mathrm{C} 3-\mathrm{C} 4-\mathrm{O} 4$ & $1.9(7)$ \\
\hline $\mathrm{C} 2-\mathrm{C} 3-\mathrm{C} 4-\mathrm{C} 4 \mathrm{~A}$ & $1.1(6)$ \\
\hline $\mathrm{C} 31-\mathrm{C} 3-\mathrm{C} 4-\mathrm{C} 4 \mathrm{~A}$ & $-177.8(4)$ \\
\hline $\mathrm{C} 6-\mathrm{C} 5-\mathrm{C} 4 \mathrm{~A}-\mathrm{C} 8 \mathrm{~A}$ & $-1.1(6)$ \\
\hline $\mathrm{C} 6-\mathrm{C} 5-\mathrm{C} 4 \mathrm{~A}-\mathrm{C} 4$ & $178.9(4)$ \\
\hline $\mathrm{O} 4-\mathrm{C} 4-\mathrm{C} 4 \mathrm{~A}-\mathrm{C} 8 \mathrm{~A}$ & $178.1(4)$ \\
\hline $\mathrm{C} 3-\mathrm{C} 4-\mathrm{C} 4 \mathrm{~A}-\mathrm{C} 8 \mathrm{~A}$ & $-2.2(6)$ \\
\hline $\mathrm{O} 4-\mathrm{C} 4-\mathrm{C} 4 \mathrm{~A}-\mathrm{C} 5$ & $-1.9(6)$ \\
\hline $\mathrm{C} 3-\mathrm{C} 4-\mathrm{C} 4 \mathrm{~A}-\mathrm{C} 5$ & $177.8(4)$ \\
\hline $\mathrm{C} 4 \mathrm{~A}-\mathrm{C} 5-\mathrm{C} 6-\mathrm{C} 7$ & $0.2(7)$ \\
\hline $\mathrm{C} 5-\mathrm{C} 6-\mathrm{C} 7-\mathrm{C} 8$ & $0.5(7)$ \\
\hline $\mathrm{C} 6-\mathrm{C} 7-\mathrm{C} 8-\mathrm{C} 8 \mathrm{~A}$ & $-0.4(7)$ \\
\hline $\mathrm{C} 5-\mathrm{C} 4 \mathrm{~A}-\mathrm{C} 8 \mathrm{~A}-\mathrm{O} 1$ & $-178.5(4)$ \\
\hline $\mathrm{C} 4-\mathrm{C} 4 \mathrm{~A}-\mathrm{C} 8 \mathrm{~A}-\mathrm{O} 1$ & $1.5(6)$ \\
\hline $\mathrm{C} 5-\mathrm{C} 4 \mathrm{~A}-\mathrm{C} 8 \mathrm{~A}-\mathrm{C} 8$ & $1.2(7)$ \\
\hline $\mathrm{C} 4-\mathrm{C} 4 \mathrm{~A}-\mathrm{C} 8 \mathrm{~A}-\mathrm{C} 8$ & $-178.8(4)$ \\
\hline $\mathrm{C} 2-\mathrm{O} 1-\mathrm{C} 8 \mathrm{~A}-\mathrm{C} 4 \mathrm{~A}$ & $0.5(6)$ \\
\hline
\end{tabular}

$\mathrm{C} 4 \mathrm{~A}-\mathrm{C} 8 \mathrm{~A}-\mathrm{C} 8$

$\mathrm{O} 1-\mathrm{C} 8 \mathrm{~A}-\mathrm{C} 8$

$\mathrm{O} 3-\mathrm{C} 31-\mathrm{N} 3$

$\mathrm{O} 3-\mathrm{C} 31-\mathrm{C} 3$

$\mathrm{N} 3-\mathrm{C} 31-\mathrm{C} 3$

$\mathrm{N} 33-\mathrm{C} 32-\mathrm{N} 3$

$\mathrm{N} 33-\mathrm{C} 32-\mathrm{S} 31$

N3-C32-S31

$\mathrm{C} 35-\mathrm{C} 34-\mathrm{N} 33$

$\mathrm{C} 35-\mathrm{C} 34-\mathrm{H} 34$

N33-C34-H34

$\mathrm{C} 34-\mathrm{C} 35-\mathrm{C} 351$

$\mathrm{C} 34-\mathrm{C} 35-\mathrm{S} 31$

C351-C35-S31

$\mathrm{C} 35-\mathrm{C} 351-\mathrm{H} 35 \mathrm{~A}$

C $35-\mathrm{C} 351-\mathrm{H} 35 \mathrm{~B}$

$\mathrm{H} 35 \mathrm{~A}-\mathrm{C} 351-\mathrm{H} 35 \mathrm{~B}$

C35-C $351-\mathrm{H} 35 \mathrm{C}$

H35A-C $351-\mathrm{H} 35 \mathrm{C}$

$\mathrm{H} 35 \mathrm{~B}-\mathrm{C} 351-\mathrm{H} 35 \mathrm{C}$

$\mathrm{C} 2-\mathrm{O} 1-\mathrm{C} 8 \mathrm{~A}-\mathrm{C} 8$

$\mathrm{C} 7-\mathrm{C} 8-\mathrm{C} 8 \mathrm{~A}-\mathrm{C} 4 \mathrm{~A}$

$\mathrm{C} 7-\mathrm{C} 8-\mathrm{C} 8 \mathrm{~A}-\mathrm{O} 1$

$\mathrm{C} 32-\mathrm{N} 3-\mathrm{C} 31-\mathrm{O} 3$

$\mathrm{C} 32-\mathrm{N} 3-\mathrm{C} 31-\mathrm{C} 3$

$\mathrm{C} 2-\mathrm{C} 3-\mathrm{C} 31-\mathrm{O} 3$

$\mathrm{C} 4-\mathrm{C} 3-\mathrm{C} 31-\mathrm{O} 3$

$\mathrm{C} 2-\mathrm{C} 3-\mathrm{C} 31-\mathrm{N} 3$

$\mathrm{C} 4-\mathrm{C} 3-\mathrm{C} 31-\mathrm{N} 3$

C34-N33-C $32-\mathrm{N} 3$

C34-N33-C32-S31

$\mathrm{C} 31-\mathrm{N} 3-\mathrm{C} 32-\mathrm{N} 33$

$\mathrm{C} 31-\mathrm{N} 3-\mathrm{C} 32-\mathrm{S} 31$

$\mathrm{C} 35-\mathrm{S} 31-\mathrm{C} 32-\mathrm{N} 33$

$\mathrm{C} 35-\mathrm{S} 31-\mathrm{C} 32-\mathrm{N} 3$

$\mathrm{C} 32-\mathrm{N} 33-\mathrm{C} 34-\mathrm{C} 35$

N33-C34-C35-C351

N33-C34-C35-S31

$\mathrm{C} 32-\mathrm{S} 31-\mathrm{C} 35-\mathrm{C} 34$

C32-S31-C35-C351
$123.2(4)$

$115.6(4)$

$122.9(4)$

$122.4(4)$

$114.8(4)$

120.2 (4)

116.1 (4)

123.7 (4)

$117.2(5)$

121.4

121.4

$128.4(5)$

109.4 (4)

122.1 (4)

109.5

109.5

109.5

109.5

109.5

109.5

$-179.3(4)$

-0.5 (7)

179.3 (4)

2.9 (7)

-177.4 (4)

$1.5(6)$

-179.6 (4)

-178.2 (4)

0.7 (6)

-178.9 (4)

-0.4 (5)

180.0 (4)

$1.6(6)$

-0.2 (4)

178.3 (4)

0.9 (6)

$179.2(4)$

$-1.1(6)$

0.7 (4)

-179.5 (4)

Hydrogen-bond geometry $\left(\AA,{ }^{\circ}\right)$

\begin{tabular}{lllll}
\hline$D-\mathrm{H} \cdots A$ & $D-\mathrm{H}$ & $\mathrm{H} \cdots A$ & $D \cdots A$ & $D-\mathrm{H} \cdots A$ \\
\hline $\mathrm{N} 3-\mathrm{H} 3 \cdots \mathrm{O} 4$ & 0.88 & 1.96 & $2.687(5)$ & 139
\end{tabular}




\begin{tabular}{llllr}
$\mathrm{C} 2-\mathrm{H} 2 \cdots \mathrm{O} 4^{\mathrm{i}}$ & 0.95 & 2.38 & $3.030(5)$ & 126 \\
$\mathrm{C} 8-\mathrm{H} 8 \cdots \mathrm{N} 33^{\mathrm{i}}$ & 0.95 & 2.56 & $3.455(6)$ & 157 \\
\hline
\end{tabular}

Symmetry code: (i) $-x+1 / 2, y+1 / 2,-z+1 / 2$.

(1_P2 1 _C)

Crystal data

$\mathrm{C}_{14} \mathrm{H}_{10} \mathrm{~N}_{2} \mathrm{O}_{3} \mathrm{~S}$

$M_{r}=286.30$

Monoclinic, $P 2_{1} / c$

$a=7.4646(5) \AA$

$b=30.626(2) \AA$

$c=11.0869(8) \AA$

$\beta=93.232(2)^{\circ}$

$V=2530.6(3) \AA^{3}$

$Z=8$

\section{Data collection}

Rigaku Saturn724+ diffractometer

Radiation source: Sealed Tube

Graphite Monochromator monochromator

Detector resolution: 28.5714 pixels $\mathrm{mm}^{-1}$

profile data from $\omega$-scans

Absorption correction: multi-scan

(CrystalClear-SM Expert; Rigaku, 2012)

$T_{\min }=0.538, T_{\max }=1.000$

\section{Refinement}

Refinement on $F^{2}$

Least-squares matrix: full

$R\left[F^{2}>2 \sigma\left(F^{2}\right)\right]=0.060$

$w R\left(F^{2}\right)=0.153$

$S=1.08$

5716 reflections

371 parameters

0 restraints
$F(000)=1184$

$D_{\mathrm{x}}=1.503 \mathrm{Mg} \mathrm{m}^{-3}$

Mo $K \alpha$ radiation, $\lambda=0.71075 \AA$

Cell parameters from 12722 reflections

$\theta=2.3-27.5^{\circ}$

$\mu=0.26 \mathrm{~mm}^{-1}$

$T=100 \mathrm{~K}$

Plate, colourless

$0.06 \times 0.06 \times 0.01 \mathrm{~mm}$

15726 measured reflections

5716 independent reflections

3733 reflections with $I>2 \sigma(I)$

$R_{\text {int }}=0.090$

$\theta_{\max }=27.5^{\circ}, \theta_{\min }=2.3^{\circ}$

$h=-8 \rightarrow 9$

$k=-37 \rightarrow 39$

$l=-14 \rightarrow 14$

Special details

Geometry. All esds (except the esd in the dihedral angle between two 1.s. planes) are estimated using the full covariance matrix. The cell esds are taken into account individually in the estimation of esds in distances, angles and torsion angles; correlations between esds in cell parameters are only used when they are defined by crystal symmetry. An approximate (isotropic) treatment of cell esds is used for estimating esds involving 1.s. planes.

Fractional atomic coordinates and isotropic or equivalent isotropic displacement parameters $\left(\AA^{2}\right)$

\begin{tabular}{lllll}
\hline & $x$ & $y$ & $z$ & $U_{\text {iso }} * / U_{\text {eq }}$ \\
\hline S131 & $0.61048(10)$ & $0.46741(2)$ & $0.38319(7)$ & $0.01951(19)$ \\
S231 & $0.12461(10)$ & $0.35373(2)$ & $0.43837(8)$ & $0.0231(2)$ \\
O11 & $0.7012(3)$ & $0.25605(6)$ & $0.53314(18)$ & $0.0193(5)$ \\
O14 & $0.4476(3)$ & $0.30431(6)$ & $0.22432(19)$ & $0.0210(5)$ \\
O21 & $0.1940(3)$ & $0.13877(6)$ & $0.52234(19)$ & $0.0211(5)$ \\
O24 & $-0.0676(3)$ & $0.19810(6)$ & $0.2322(2)$ & $0.0221(5)$
\end{tabular}




\begin{tabular}{|c|c|c|c|c|}
\hline O131 & $0.6665(3)$ & $0.38847(6)$ & $0.49383(19)$ & $0.0213(5)$ \\
\hline $\mathrm{O} 231$ & $0.1912(3)$ & $0.27146(7)$ & $0.5128(2)$ & $0.0254(5)$ \\
\hline N13 & $0.5367(3)$ & $0.38401(8)$ & $0.3050(2)$ & $0.0187(6)$ \\
\hline N23 & $0.0312(3)$ & $0.27500(8)$ & $0.3342(3)$ & $0.0198(6)$ \\
\hline N133 & $0.4688(4)$ & $0.44311(8)$ & $0.1763(2)$ & $0.0259(6)$ \\
\hline N233 & $-0.0482(3)$ & $0.33985(8)$ & $0.2334(2)$ & $0.0232(6)$ \\
\hline $\mathrm{C} 12$ & $0.6872(4)$ & $0.29895(9)$ & $0.5127(3)$ & $0.0177(6)$ \\
\hline H12 & 0.7403 & 0.3180 & 0.5722 & $0.021^{*}$ \\
\hline $\mathrm{C} 13$ & $0.6033(4)$ & $0.31749(9)$ & $0.4141(3)$ & $0.0166(6)$ \\
\hline $\mathrm{C} 14$ & $0.5230(4)$ & $0.29002(9)$ & $0.3192(3)$ & $0.0161(6)$ \\
\hline $\mathrm{C} 15$ & $0.4645(4)$ & $0.21215(9)$ & $0.2591(3)$ & $0.0182(6)$ \\
\hline H15 & 0.4032 & 0.2216 & 0.1863 & $0.022 *$ \\
\hline $\mathrm{C} 14 \mathrm{~A}$ & $0.5380(4)$ & $0.24282(9)$ & $0.3424(3)$ & $0.0170(6)$ \\
\hline $\mathrm{C} 16$ & $0.4824(4)$ & $0.16821(9)$ & $0.2840(3)$ & $0.0191(7)$ \\
\hline H16 & 0.4344 & 0.1474 & 0.2275 & $0.023^{*}$ \\
\hline $\mathrm{C} 17$ & $0.5706(4)$ & $0.15392(9)$ & $0.3917(3)$ & $0.0209(7)$ \\
\hline H17 & 0.5808 & 0.1235 & 0.4078 & $0.025^{*}$ \\
\hline $\mathrm{C} 18$ & $0.6425(4)$ & $0.18345(9)$ & $0.4745(3)$ & $0.0190(6)$ \\
\hline H1 8 & 0.7022 & 0.1739 & 0.5477 & $0.023^{*}$ \\
\hline C18A & $0.6252(4)$ & $0.22810(9)$ & $0.4478(3)$ & $0.0163(6)$ \\
\hline $\mathrm{C} 22$ & $0.1841(4)$ & $0.18235(9)$ & $0.5132(3)$ & $0.0204(7)$ \\
\hline $\mathrm{H} 22$ & 0.2399 & 0.1992 & 0.5768 & $0.024 *$ \\
\hline $\mathrm{C} 23$ & $0.1006(4)$ & $0.20402(9)$ & $0.4203(3)$ & $0.0171(6)$ \\
\hline $\mathrm{C} 24$ & $0.0102(4)$ & $0.18040(10)$ & $0.3211(3)$ & $0.0183(6)$ \\
\hline $\mathrm{C} 25$ & $-0.0718(4)$ & $0.10459(9)$ & $0.2489(3)$ & $0.0198(6)$ \\
\hline $\mathrm{H} 25$ & -0.1343 & 0.1165 & 0.1795 & $0.024 *$ \\
\hline $\mathrm{C} 24 \mathrm{~A}$ & $0.0162(4)$ & $0.13245(9)$ & $0.3338(3)$ & $0.0185(6)$ \\
\hline $\mathrm{C} 26$ & $-0.0676(4)$ & $0.06024(10)$ & $0.2662(3)$ & $0.0245(7)$ \\
\hline H26 & -0.1286 & 0.0416 & 0.2090 & $0.029 *$ \\
\hline $\mathrm{C} 27$ & $0.0260(4)$ & $0.04218(10)$ & $0.3673(3)$ & $0.0268(7)$ \\
\hline $\mathrm{H} 27$ & 0.0280 & 0.0114 & 0.3784 & $0.032 *$ \\
\hline $\mathrm{C} 28$ & $0.1153(4)$ & $0.06891(10)$ & $0.4511(3)$ & $0.0240(7)$ \\
\hline H28 & 0.1811 & 0.0569 & 0.5190 & $0.029 *$ \\
\hline $\mathrm{C} 28 \mathrm{~A}$ & 0.1069 (4) & $0.11384(9)$ & $0.4338(3)$ & $0.0192(6)$ \\
\hline $\mathrm{C} 132$ & $0.5337(4)$ & $0.42830(9)$ & $0.2799(3)$ & $0.0189(6)$ \\
\hline C134 & $0.4804(4)$ & $0.48808(10)$ & $0.1767(3)$ & $0.0277(8)$ \\
\hline H134 & 0.4396 & 0.5048 & 0.1084 & $0.033^{*}$ \\
\hline C135 & $0.5518(4)$ & $0.50732(9)$ & $0.2774(3)$ & $0.0210(7)$ \\
\hline C136 & $0.5782(4)$ & $0.55514(9)$ & $0.3022(3)$ & $0.0264(8)$ \\
\hline H13A & 0.5545 & 0.5717 & 0.2273 & $0.040^{*}$ \\
\hline H13B & 0.7020 & 0.5603 & 0.3330 & $0.040^{*}$ \\
\hline $\mathrm{H} 13 \mathrm{C}$ & 0.4953 & 0.5646 & 0.3624 & $0.040^{*}$ \\
\hline $\mathrm{C} 137$ & $0.6058(4)$ & $0.36610(9)$ & $0.4097(3)$ & $0.0164(6)$ \\
\hline C232 & $0.0293(4)$ & $0.32010(9)$ & $0.3258(3)$ & $0.0190(6)$ \\
\hline C234 & $-0.0323(4)$ & $0.38469(10)$ & $0.2497(3)$ & 0.0255 \\
\hline $\mathrm{H} 234$ & -0.0807 & 0.4047 & 0.1910 & $0.031^{*}$ \\
\hline $\mathrm{C} 235$ & $0.0546(4)$ & $0.39855(10)$ & $0.3522(3)$ & $0.0249(7)$ \\
\hline C236 & $0.0899(4)$ & $0.44428(10)$ & $0.3955(3)$ & $0.0302(8)$ \\
\hline
\end{tabular}




$\begin{array}{lllll}\mathrm{H} 23 \mathrm{~A} & 0.0396 & 0.4650 & 0.3353 & 0.045^{*} \\ \mathrm{H} 23 \mathrm{~B} & 0.2196 & 0.4490 & 0.4071 & 0.045^{*} \\ \mathrm{H} 23 \mathrm{C} & 0.0337 & 0.4488 & 0.4723 & 0.045^{*} \\ \mathrm{C} 237 & 0.1123(4) & 0.25267(10) & 0.4275(3) & 0.0190(6) \\ \mathrm{H} 13 & 0.499(5) & 0.3673(12) & 0.255(3) & 0.036(11)^{*} \\ \mathrm{H} 23 & -0.012(5) & 0.2620(11) & 0.275(3) & 0.032(11)^{*}\end{array}$

Atomic displacement parameters $\left(\AA^{2}\right)$

\begin{tabular}{|c|c|c|c|c|c|c|}
\hline & $U^{11}$ & $U^{22}$ & $U^{33}$ & $U^{12}$ & $U^{13}$ & $U^{23}$ \\
\hline S131 & $0.0231(4)$ & $0.0159(3)$ & $0.0195(4)$ & 0.0003 & 0.0008 & $-0.0002(3)$ \\
\hline S231 & $0.0199(4)$ & 0.0218 & $0.0277(5)$ & $0.0002(3)$ & 0.0006 & $-0.0048(3)$ \\
\hline O11 & $0.0246(10)$ & $0.0178(10)$ & $0.0152(12)$ & $-0.0001(8)$ & $-0.0014(9)$ & $0.0000(9)$ \\
\hline $\mathrm{O} 14$ & $0.0267(11)$ & $0.0184(10)$ & $0.0171(12)$ & $0.0018(8)$ & $-0.0062(10)$ & $0.0013(9)$ \\
\hline $\mathrm{O} 21$ & $0.0243(11)$ & 0.0237 (11) & $0.0152(12)$ & $0.0017(9)$ & $-0.0007(9)$ & $0.0011(9)$ \\
\hline $\mathrm{O} 24$ & $0.0275(11)$ & $0.0217(11)$ & $0.0167(12)$ & $-0.0010(9)$ & $-0.0041(10)$ & $0.0007(9)$ \\
\hline O131 & $0.0270(11)$ & $0.0198(10)$ & $0.0167(12)$ & $-0.0008(8)$ & $-0.0016(10)$ & $-0.0025(9)$ \\
\hline $\mathrm{O} 231$ & $0.0274(11)$ & $0.0256(11)$ & $0.0224(13)$ & $0.0002(9)$ & $-0.0064(10)$ & $-0.0056(10)$ \\
\hline N13 & $0.0240(14)$ & $0.0158(12)$ & 0.0159 (14) & $-0.0007(10)$ & $-0.0016(12)$ & $-0.0013(11)$ \\
\hline $\mathrm{N} 23$ & $0.0209(13)$ & $0.0196(13)$ & $0.0189(15)$ & $-0.0007(10)$ & $0.0010(12)$ & $-0.0030(11)$ \\
\hline N133 & $0.0344(15)$ & 0.0225 & $0.0202(15)$ & $0.0010(11)$ & $-0.0038(13)$ & $0.0032(11)$ \\
\hline N233 & $0.0266(13)$ & $0.0237(13)$ & $0.0197(15)$ & $0.0002(11)$ & $0.0040(12)$ & $0.0020(11)$ \\
\hline $\mathrm{C} 12$ & $0.0201(14)$ & $0.0166(13)$ & $0.0164(16)$ & $-0.0023(11)$ & $0.0006(13)$ & $-0.0027(12)$ \\
\hline $\mathrm{C} 13$ & $0.0156(13)$ & $0.0220(14)$ & $0.0125(15)$ & $-0.0005(11)$ & $0.0027(12)$ & $0.0000(12)$ \\
\hline $\mathrm{C} 14$ & $0.0154(13)$ & $0.0192(14)$ & $0.0138(16)$ & $0.0025(11)$ & $0.0015(12)$ & $-0.0011(12)$ \\
\hline $\mathrm{C} 15$ & 0.0179 (14) & $0.0220(14)$ & $0.0149(16)$ & $-0.0012(11)$ & $0.0027(13)$ & $-0.0023(12)$ \\
\hline C14A & $0.0153(14)$ & $0.0210(14)$ & $0.0151(16)$ & $0.0006(11)$ & $0.0053(12)$ & $-0.0003(12)$ \\
\hline C16 & $0.0210(14)$ & $0.0176(14)$ & $0.0191(17)$ & $-0.0033(11)$ & $0.0044(13)$ & $-0.0069(12)$ \\
\hline $\mathrm{C} 17$ & $0.0229(15)$ & $0.0171(14)$ & $0.0232(18)$ & $0.0006(11)$ & $0.0061(14)$ & $-0.0005(13)$ \\
\hline $\mathrm{C} 18$ & 0.0207 (14) & 0.0199 (14) & $0.0168(16)$ & 0.0004 (11) & $0.0040(13)$ & $0.0032(12)$ \\
\hline C18A & $0.0153(13)$ & $0.0241(14)$ & $0.0096(15)$ & $-0.0015(11)$ & $0.0011(12)$ & $-0.0043(12)$ \\
\hline $\mathrm{C} 22$ & $0.0193(14)$ & $0.0230(15)$ & $0.0189(17)$ & $-0.0013(12)$ & $0.0014(13)$ & $-0.0008(13)$ \\
\hline $\mathrm{C} 23$ & $0.0141(13)$ & $0.0235(15)$ & $0.0138(16)$ & $0.0002(11)$ & $0.0023(12)$ & $0.0005(12)$ \\
\hline $\mathrm{C} 24$ & $0.0170(14)$ & $0.0251(15)$ & $0.0128(15)$ & $-0.0011(12)$ & $0.0016(12)$ & $0.0020(12)$ \\
\hline $\mathrm{C} 25$ & $0.0190(14)$ & $0.0238(14)$ & 0.0163 (17) & $-0.0013(12)$ & $-0.0013(13)$ & $-0.0008(13)$ \\
\hline $\mathrm{C} 24 \mathrm{~A}$ & $0.0183(14)$ & $0.0230(15)$ & $0.0145(16)$ & $0.0020(11)$ & 0.0037 (13) & $0.0009(12)$ \\
\hline $\mathrm{C} 26$ & $0.0276(16)$ & $0.0228(15)$ & $0.0231(18)$ & $-0.0022(13)$ & $0.0018(15)$ & $-0.0024(14)$ \\
\hline $\mathrm{C} 27$ & $0.0302(17)$ & $0.0193(15)$ & $0.031(2)$ & 0.0003 (13) & $0.0061(16)$ & $0.0029(14)$ \\
\hline $\mathrm{C} 28$ & $0.0240(15)$ & $0.0268(16)$ & $0.0215(18)$ & $0.0046(13)$ & $0.0023(14)$ & $0.0058(14)$ \\
\hline C28A & $0.0198(14)$ & 0.0219 (14) & $0.0163(16)$ & $-0.0002(11)$ & $0.0043(13)$ & $-0.0002(13)$ \\
\hline C132 & $0.0188(14)$ & $0.0189(14)$ & $0.0190(17)$ & $-0.0004(11)$ & 0.0015 (13) & -0.0015 \\
\hline C134 & $0.0374(18)$ & $0.0185(15)$ & $0.027(2)$ & $0.0024(13)$ & $-0.0001(16)$ & $0.0053(14)$ \\
\hline C135 & $0.0196(14)$ & $0.0195(14)$ & $0.0242(18)$ & $0.0015(12)$ & 0.0047 (14) & $0.0040(13)$ \\
\hline C136 & $0.0325(17)$ & $0.0174(15)$ & $0.030(2)$ & $-0.0011(13)$ & $0.0071(16)$ & $0.0035(14)$ \\
\hline C137 & $0.0128(13)$ & 0.0199 (14) & $0.0162(17)$ & $-0.0013(11)$ & $-0.0011(12)$ & $-0.0006(12)$ \\
\hline $\mathrm{C} 232$ & $0.0187(14)$ & $0.0212(14)$ & $0.0172(16)$ & $-0.0003(11)$ & $0.0023(13)$ & $-0.0006(13)$ \\
\hline $\mathrm{C} 234$ & $0.0291(17)$ & $0.0229(15)$ & 0.0255 (19) & $0.0014(13)$ & $0.0096(15)$ & $0.0009(14)$ \\
\hline $\mathrm{C} 235$ & $0.0200(15)$ & $0.0202(15)$ & $0.035(2)$ & $-0.0018(12)$ & $0.0093(15)$ & $-0.0016(14)$ \\
\hline
\end{tabular}




\begin{tabular}{lllllll}
$\mathrm{C} 236$ & $0.0242(16)$ & $0.0253(16)$ & $0.041(2)$ & $-0.0004(13)$ & $0.0024(16)$ & $-0.0040(16)$ \\
$\mathrm{C} 237$ & $0.0158(13)$ & $0.0240(15)$ & $0.0172(16)$ & $0.0012(11)$ & $0.0010(13)$ & $-0.0035(13)$ \\
\hline
\end{tabular}

Geometric parameters $\left(\AA,{ }^{\circ}\right)$

\begin{tabular}{|c|c|c|c|}
\hline $\mathrm{S} 131-\mathrm{C} 132$ & $1.732(3)$ & $\mathrm{C} 16-\mathrm{H} 16$ & 0.9500 \\
\hline $\mathrm{S} 131-\mathrm{C} 135$ & $1.733(3)$ & $\mathrm{C} 17-\mathrm{C} 18$ & $1.376(4)$ \\
\hline $\mathrm{S} 231-\mathrm{C} 235$ & $1.736(3)$ & $\mathrm{C} 17-\mathrm{H} 17$ & 0.9500 \\
\hline S231-C232 & $1.739(3)$ & $\mathrm{C} 18-\mathrm{C} 18 \mathrm{~A}$ & $1.404(4)$ \\
\hline $\mathrm{O} 11-\mathrm{C} 12$ & $1.336(3)$ & $\mathrm{C} 18-\mathrm{H} 18$ & 0.9500 \\
\hline $\mathrm{O} 11-\mathrm{C} 18 \mathrm{~A}$ & $1.374(3)$ & $\mathrm{C} 22-\mathrm{C} 23$ & $1.348(4)$ \\
\hline $\mathrm{O} 14-\mathrm{C} 14$ & $1.244(4)$ & $\mathrm{C} 22-\mathrm{H} 22$ & 0.9500 \\
\hline $\mathrm{O} 21-\mathrm{C} 22$ & $1.340(3)$ & $\mathrm{C} 23-\mathrm{C} 24$ & $1.450(4)$ \\
\hline $\mathrm{O} 21-\mathrm{C} 28 \mathrm{~A}$ & $1.377(4)$ & $\mathrm{C} 23-\mathrm{C} 237$ & $1.495(4)$ \\
\hline $\mathrm{O} 24-\mathrm{C} 24$ & $1.241(4)$ & $\mathrm{C} 24-\mathrm{C} 24 \mathrm{~A}$ & $1.476(4)$ \\
\hline $\mathrm{O} 131-\mathrm{C} 137$ & $1.223(3)$ & $\mathrm{C} 25-\mathrm{C} 26$ & $1.372(4)$ \\
\hline $\mathrm{O} 231-\mathrm{C} 237$ & $1.229(4)$ & $\mathrm{C} 25-\mathrm{C} 24 \mathrm{~A}$ & $1.405(4)$ \\
\hline $\mathrm{N} 13-\mathrm{C} 137$ & $1.359(4)$ & $\mathrm{C} 25-\mathrm{H} 25$ & 0.9500 \\
\hline $\mathrm{N} 13-\mathrm{C} 132$ & $1.385(4)$ & $\mathrm{C} 24 \mathrm{~A}-\mathrm{C} 28 \mathrm{~A}$ & $1.389(4)$ \\
\hline N13-H13 & $0.80(4)$ & $\mathrm{C} 26-\mathrm{C} 27$ & $1.401(5)$ \\
\hline $\mathrm{N} 23-\mathrm{C} 237$ & $1.354(4)$ & $\mathrm{C} 26-\mathrm{H} 26$ & 0.9500 \\
\hline $\mathrm{N} 23-\mathrm{C} 232$ & $1.384(4)$ & $\mathrm{C} 27-\mathrm{C} 28$ & $1.381(4)$ \\
\hline $\mathrm{N} 23-\mathrm{H} 23$ & $0.82(4)$ & $\mathrm{C} 27-\mathrm{H} 27$ & 0.9500 \\
\hline N133-C132 & $1.302(4)$ & $\mathrm{C} 28-\mathrm{C} 28 \mathrm{~A}$ & $1.390(4)$ \\
\hline N133-C134 & $1.380(4)$ & $\mathrm{C} 28-\mathrm{H} 28$ & 0.9500 \\
\hline $\mathrm{N} 233-\mathrm{C} 232$ & $1.297(4)$ & $\mathrm{C} 134-\mathrm{C} 135$ & $1.345(5)$ \\
\hline $\mathrm{N} 233-\mathrm{C} 234$ & $1.389(4)$ & C134-H134 & 0.9500 \\
\hline $\mathrm{C} 12-\mathrm{C} 13$ & $1.354(4)$ & $\mathrm{C} 135-\mathrm{C} 136$ & $1.501(4)$ \\
\hline $\mathrm{C} 12-\mathrm{H} 12$ & 0.9500 & $\mathrm{C} 136-\mathrm{H} 13 \mathrm{~A}$ & 0.9800 \\
\hline $\mathrm{C} 13-\mathrm{C} 14$ & $1.451(4)$ & C136- H13B & 0.9800 \\
\hline $\mathrm{C} 13-\mathrm{C} 137$ & $1.490(4)$ & $\mathrm{C} 136-\mathrm{H} 13 \mathrm{C}$ & 0.9800 \\
\hline $\mathrm{C} 14-\mathrm{C} 14 \mathrm{~A}$ & $1.472(4)$ & $\mathrm{C} 234-\mathrm{C} 235$ & $1.346(5)$ \\
\hline $\mathrm{C} 15-\mathrm{C} 16$ & $1.379(4)$ & $\mathrm{C} 234-\mathrm{H} 234$ & 0.9500 \\
\hline $\mathrm{C} 15-\mathrm{C} 14 \mathrm{~A}$ & $1.407(4)$ & $\mathrm{C} 235-\mathrm{C} 236$ & 1.499 (4) \\
\hline C15-H15 & 0.9500 & $\mathrm{C} 236-\mathrm{H} 23 \mathrm{~A}$ & 0.9800 \\
\hline $\mathrm{C} 14 \mathrm{~A}-\mathrm{C} 18 \mathrm{~A}$ & $1.381(4)$ & $\mathrm{C} 236-\mathrm{H} 23 \mathrm{~B}$ & 0.9800 \\
\hline $\mathrm{C} 16-\mathrm{C} 17$ & $1.401(4)$ & $\mathrm{C} 236-\mathrm{H} 23 \mathrm{C}$ & 0.9800 \\
\hline $\mathrm{C} 132-\mathrm{S} 131-\mathrm{C} 135$ & $88.76(15)$ & $\mathrm{C} 28 \mathrm{~A}-\mathrm{C} 24 \mathrm{~A}-\mathrm{C} 25$ & $118.3(3)$ \\
\hline $\mathrm{C} 235-\mathrm{S} 231-\mathrm{C} 232$ & $88.58(16)$ & $\mathrm{C} 28 \mathrm{~A}-\mathrm{C} 24 \mathrm{~A}-\mathrm{C} 24$ & $119.7(3)$ \\
\hline $\mathrm{C} 12-\mathrm{O} 11-\mathrm{C} 18 \mathrm{~A}$ & $118.0(2)$ & $\mathrm{C} 25-\mathrm{C} 24 \mathrm{~A}-\mathrm{C} 24$ & $122.0(3)$ \\
\hline $\mathrm{C} 22-\mathrm{O} 21-\mathrm{C} 28 \mathrm{~A}$ & $118.4(2)$ & $\mathrm{C} 25-\mathrm{C} 26-\mathrm{C} 27$ & $120.6(3)$ \\
\hline $\mathrm{C} 137-\mathrm{N} 13-\mathrm{C} 132$ & $124.6(3)$ & $\mathrm{C} 25-\mathrm{C} 26-\mathrm{H} 26$ & 119.7 \\
\hline C137-N13-H13 & $116(3)$ & $\mathrm{C} 27-\mathrm{C} 26-\mathrm{H} 26$ & 119.7 \\
\hline $\mathrm{C} 132-\mathrm{N} 13-\mathrm{H} 13$ & $119(3)$ & $\mathrm{C} 28-\mathrm{C} 27-\mathrm{C} 26$ & $120.3(3)$ \\
\hline $\mathrm{C} 237-\mathrm{N} 23-\mathrm{C} 232$ & $123.9(3)$ & $\mathrm{C} 28-\mathrm{C} 27-\mathrm{H} 27$ & 119.9 \\
\hline $\mathrm{C} 237-\mathrm{N} 23-\mathrm{H} 23$ & $120(3)$ & $\mathrm{C} 26-\mathrm{C} 27-\mathrm{H} 27$ & 119.9 \\
\hline $\mathrm{C} 232-\mathrm{N} 23-\mathrm{H} 23$ & $116(3)$ & $\mathrm{C} 27-\mathrm{C} 28-\mathrm{C} 28 \mathrm{~A}$ & $118.6(3)$ \\
\hline
\end{tabular}




\begin{tabular}{|c|c|}
\hline $\mathrm{C} 132-\mathrm{N} 133-\mathrm{C} 134$ & $109.0(3)$ \\
\hline $\mathrm{C} 232-\mathrm{N} 233-\mathrm{C} 234$ & $109.1(3)$ \\
\hline $\mathrm{O} 11-\mathrm{C} 12-\mathrm{C} 13$ & $125.3(3)$ \\
\hline $\mathrm{O} 11-\mathrm{C} 12-\mathrm{H} 12$ & 117.3 \\
\hline $\mathrm{C} 13-\mathrm{C} 12-\mathrm{H} 12$ & 117.3 \\
\hline $\mathrm{C} 12-\mathrm{C} 13-\mathrm{C} 14$ & $119.7(3)$ \\
\hline $\mathrm{C} 12-\mathrm{C} 13-\mathrm{C} 137$ & $116.1(3)$ \\
\hline $\mathrm{C} 14-\mathrm{C} 13-\mathrm{C} 137$ & $124.1(3)$ \\
\hline $\mathrm{O} 14-\mathrm{C} 14-\mathrm{C} 13$ & $123.9(3)$ \\
\hline $\mathrm{O} 14-\mathrm{C} 14-\mathrm{C} 14 \mathrm{~A}$ & $121.3(3)$ \\
\hline $\mathrm{C} 13-\mathrm{C} 14-\mathrm{C} 14 \mathrm{~A}$ & $114.7(3)$ \\
\hline $\mathrm{C} 16-\mathrm{C} 15-\mathrm{C} 14 \mathrm{~A}$ & $119.3(3)$ \\
\hline $\mathrm{C} 16-\mathrm{C} 15-\mathrm{H} 15$ & 120.3 \\
\hline $\mathrm{C} 14 \mathrm{~A}-\mathrm{C} 15-\mathrm{H} 15$ & 120.3 \\
\hline $\mathrm{C} 18 \mathrm{~A}-\mathrm{C} 14 \mathrm{~A}-\mathrm{C} 15$ & $119.0(3)$ \\
\hline $\mathrm{C} 18 \mathrm{~A}-\mathrm{C} 14 \mathrm{~A}-\mathrm{C} 14$ & $119.8(3)$ \\
\hline $\mathrm{C} 15-\mathrm{C} 14 \mathrm{~A}-\mathrm{C} 14$ & $121.2(3)$ \\
\hline $\mathrm{C} 15-\mathrm{C} 16-\mathrm{C} 17$ & $120.8(3)$ \\
\hline $\mathrm{C} 15-\mathrm{C} 16-\mathrm{H} 16$ & 119.6 \\
\hline $\mathrm{C} 17-\mathrm{C} 16-\mathrm{H} 16$ & 119.6 \\
\hline $\mathrm{C} 18-\mathrm{C} 17-\mathrm{C} 16$ & $120.7(3)$ \\
\hline $\mathrm{C} 18-\mathrm{C} 17-\mathrm{H} 17$ & 119.7 \\
\hline $\mathrm{C} 16-\mathrm{C} 17-\mathrm{H} 17$ & 119.7 \\
\hline $\mathrm{C} 17-\mathrm{C} 18-\mathrm{C} 18 \mathrm{~A}$ & $118.1(3)$ \\
\hline $\mathrm{C} 17-\mathrm{C} 18-\mathrm{H} 18$ & 120.9 \\
\hline $\mathrm{C} 18 \mathrm{~A}-\mathrm{C} 18-\mathrm{H} 18$ & 120.9 \\
\hline $\mathrm{O} 11-\mathrm{C} 18 \mathrm{~A}-\mathrm{C} 14 \mathrm{~A}$ & $122.4(3)$ \\
\hline $\mathrm{O} 11-\mathrm{C} 18 \mathrm{~A}-\mathrm{C} 18$ & $115.6(3)$ \\
\hline $\mathrm{C} 14 \mathrm{~A}-\mathrm{C} 18 \mathrm{~A}-\mathrm{C} 18$ & $122.0(3)$ \\
\hline $\mathrm{O} 21-\mathrm{C} 22-\mathrm{C} 23$ & $124.7(3)$ \\
\hline $\mathrm{O} 21-\mathrm{C} 22-\mathrm{H} 22$ & 117.7 \\
\hline $\mathrm{C} 23-\mathrm{C} 22-\mathrm{H} 22$ & 117.7 \\
\hline $\mathrm{C} 22-\mathrm{C} 23-\mathrm{C} 24$ & $120.6(3)$ \\
\hline $\mathrm{C} 22-\mathrm{C} 23-\mathrm{C} 237$ & 115.3 \\
\hline $\mathrm{C} 24-\mathrm{C} 23-\mathrm{C} 237$ & $124.1(3)$ \\
\hline $\mathrm{O} 24-\mathrm{C} 24-\mathrm{C} 23$ & $124.2(3)$ \\
\hline $\mathrm{O} 24-\mathrm{C} 24-\mathrm{C} 24 \mathrm{~A}$ & $121.4(3)$ \\
\hline $\mathrm{C} 23-\mathrm{C} 24-\mathrm{C} 24 \mathrm{~A}$ & $114.5(3)$ \\
\hline $\mathrm{C} 26-\mathrm{C} 25-\mathrm{C} 24 \mathrm{~A}$ & $120.1(3)$ \\
\hline $\mathrm{C} 26-\mathrm{C} 25-\mathrm{H} 25$ & 119.9 \\
\hline $\mathrm{C} 24 \mathrm{~A}-\mathrm{C} 25-\mathrm{H} 25$ & 119.9 \\
\hline $\mathrm{C} 18 \mathrm{~A}-\mathrm{O} 11-\mathrm{C} 12-\mathrm{C} 13$ & $0.1(4)$ \\
\hline $\mathrm{O} 11-\mathrm{C} 12-\mathrm{C} 13-\mathrm{C} 14$ & $-1.3(4)$ \\
\hline $\mathrm{O} 11-\mathrm{C} 12-\mathrm{C} 13-\mathrm{C} 137$ & $-179.4(2)$ \\
\hline $\mathrm{C} 12-\mathrm{C} 13-\mathrm{C} 14-\mathrm{O} 14$ & $-178.1(3)$ \\
\hline $\mathrm{C} 137-\mathrm{C} 13-\mathrm{C} 14-\mathrm{O} 14$ & $-0.1(4)$ \\
\hline $\mathrm{C} 12-\mathrm{C} 13-\mathrm{C} 14-\mathrm{C} 14 \mathrm{~A}$ & $1.5(4)$ \\
\hline
\end{tabular}

\begin{tabular}{|c|c|}
\hline $\mathrm{C} 27-\mathrm{C} 28-\mathrm{H} 28$ & 120.7 \\
\hline $\mathrm{C} 28 \mathrm{~A}-\mathrm{C} 28-\mathrm{H} 28$ & 120.7 \\
\hline $\mathrm{O} 21-\mathrm{C} 28 \mathrm{~A}-\mathrm{C} 24 \mathrm{~A}$ & $122.1(3)$ \\
\hline $\mathrm{O} 21-\mathrm{C} 28 \mathrm{~A}-\mathrm{C} 28$ & $115.8(3)$ \\
\hline $\mathrm{C} 24 \mathrm{~A}-\mathrm{C} 28 \mathrm{~A}-\mathrm{C} 28$ & $122.1(3)$ \\
\hline $\mathrm{N} 133-\mathrm{C} 132-\mathrm{N} 13$ & $121.3(3)$ \\
\hline $\mathrm{N} 133-\mathrm{C} 132-\mathrm{S} 131$ & $115.8(2)$ \\
\hline $\mathrm{N} 13-\mathrm{C} 132-\mathrm{S} 131$ & $122.9(2)$ \\
\hline $\mathrm{C} 135-\mathrm{C} 134-\mathrm{N} 133$ & $117.5(3)$ \\
\hline $\mathrm{C} 135-\mathrm{C} 134-\mathrm{H} 134$ & 121.3 \\
\hline $\mathrm{N} 133-\mathrm{C} 134-\mathrm{H} 134$ & 121.3 \\
\hline $\mathrm{C} 134-\mathrm{C} 135-\mathrm{C} 136$ & $128.4(3)$ \\
\hline $\mathrm{C} 134-\mathrm{C} 135-\mathrm{S} 131$ & $109.0(2)$ \\
\hline $\mathrm{C} 136-\mathrm{C} 135-\mathrm{S} 131$ & $122.6(3)$ \\
\hline $\mathrm{C} 135-\mathrm{C} 136-\mathrm{H} 13 \mathrm{~A}$ & 109.5 \\
\hline $\mathrm{C} 135-\mathrm{C} 136-\mathrm{H} 13 \mathrm{~B}$ & 109.5 \\
\hline $\mathrm{H} 13 \mathrm{~A}-\mathrm{C} 136-\mathrm{H} 13 \mathrm{~B}$ & 109.5 \\
\hline $\mathrm{C} 135-\mathrm{C} 136-\mathrm{H} 13 \mathrm{C}$ & 109.5 \\
\hline $\mathrm{H} 13 \mathrm{~A}-\mathrm{C} 136-\mathrm{H} 13 \mathrm{C}$ & 109.5 \\
\hline $\mathrm{H} 13 \mathrm{~B}-\mathrm{C} 136-\mathrm{H} 13 \mathrm{C}$ & 109.5 \\
\hline $\mathrm{O} 131-\mathrm{C} 137-\mathrm{N} 13$ & $122.1(3)$ \\
\hline $\mathrm{O} 131-\mathrm{C} 137-\mathrm{C} 13$ & $122.6(3)$ \\
\hline $\mathrm{N} 13-\mathrm{C} 137-\mathrm{C} 13$ & $115.2(3)$ \\
\hline $\mathrm{N} 233-\mathrm{C} 232-\mathrm{N} 23$ & $121.4(3)$ \\
\hline $\mathrm{N} 233-\mathrm{C} 232-\mathrm{S} 231$ & $115.9(2)$ \\
\hline $\mathrm{N} 23-\mathrm{C} 232-\mathrm{S} 231$ & $122.7(2)$ \\
\hline $\mathrm{C} 235-\mathrm{C} 234-\mathrm{N} 233$ & $117.1(3)$ \\
\hline $\mathrm{C} 235-\mathrm{C} 234-\mathrm{H} 234$ & 121.5 \\
\hline $\mathrm{N} 233-\mathrm{C} 234-\mathrm{H} 234$ & 121.5 \\
\hline $\mathrm{C} 234-\mathrm{C} 235-\mathrm{C} 236$ & $129.3(3)$ \\
\hline $\mathrm{C} 234-\mathrm{C} 235-\mathrm{S} 231$ & $109.3(2)$ \\
\hline $\mathrm{C} 236-\mathrm{C} 235-\mathrm{S} 231$ & $121.4(3)$ \\
\hline $\mathrm{C} 235-\mathrm{C} 236-\mathrm{H} 23 \mathrm{~A}$ & 109.5 \\
\hline $\mathrm{C} 235-\mathrm{C} 236-\mathrm{H} 23 \mathrm{~B}$ & 109.5 \\
\hline $\mathrm{H} 23 \mathrm{~A}-\mathrm{C} 236-\mathrm{H} 23 \mathrm{~B}$ & 109.5 \\
\hline $\mathrm{C} 235-\mathrm{C} 236-\mathrm{H} 23 \mathrm{C}$ & 109.5 \\
\hline $\mathrm{H} 23 \mathrm{~A}-\mathrm{C} 236-\mathrm{H} 23 \mathrm{C}$ & 109.5 \\
\hline $\mathrm{H} 23 \mathrm{~B}-\mathrm{C} 236-\mathrm{H} 23 \mathrm{C}$ & 109.5 \\
\hline $\mathrm{O} 231-\mathrm{C} 237-\mathrm{N} 23$ & $121.7(3)$ \\
\hline $\mathrm{O} 231-\mathrm{C} 237-\mathrm{C} 23$ & $122.1(3)$ \\
\hline $\mathrm{N} 23-\mathrm{C} 237-\mathrm{C} 23$ & $116.1(3)$ \\
\hline $\mathrm{C} 22-\mathrm{O} 21-\mathrm{C} 28 \mathrm{~A}-\mathrm{C} 28$ & $-177.2(2)$ \\
\hline $\mathrm{C} 25-\mathrm{C} 24 \mathrm{~A}-\mathrm{C} 28 \mathrm{~A}-\mathrm{O} 21$ & $-178.9(2)$ \\
\hline $\mathrm{C} 24-\mathrm{C} 24 \mathrm{~A}-\mathrm{C} 28 \mathrm{~A}-\mathrm{O} 21$ & $-0.6(4)$ \\
\hline $\mathrm{C} 25-\mathrm{C} 24 \mathrm{~A}-\mathrm{C} 28 \mathrm{~A}-\mathrm{C} 28$ & $1.0(4)$ \\
\hline $\mathrm{C} 24-\mathrm{C} 24 \mathrm{~A}-\mathrm{C} 28 \mathrm{~A}-\mathrm{C} 28$ & $179.3(2)$ \\
\hline $\mathrm{C} 27-\mathrm{C} 28-\mathrm{C} 28 \mathrm{~A}-\mathrm{O} 21$ & $178.0(2)$ \\
\hline
\end{tabular}




\begin{tabular}{|c|c|}
\hline $\mathrm{C} 137-\mathrm{C} 13-\mathrm{C} 14-\mathrm{C} 14 \mathrm{~A}$ & $179.4(2)$ \\
\hline $\mathrm{C} 16-\mathrm{C} 15-\mathrm{C} 14 \mathrm{~A}-\mathrm{C} 18 \mathrm{~A}$ & $-0.5(4)$ \\
\hline $\mathrm{C} 16-\mathrm{C} 15-\mathrm{C} 14 \mathrm{~A}-\mathrm{C} 14$ & $179.7(2)$ \\
\hline $\mathrm{O} 14-\mathrm{C} 14-\mathrm{C} 14 \mathrm{~A}-\mathrm{C} 18 \mathrm{~A}$ & $178.9(2)$ \\
\hline $\mathrm{C} 13-\mathrm{C} 14-\mathrm{C} 14 \mathrm{~A}-\mathrm{C} 18 \mathrm{~A}$ & $-0.6(4)$ \\
\hline $\mathrm{O} 14-\mathrm{C} 14-\mathrm{C} 14 \mathrm{~A}-\mathrm{C} 15$ & $-1.2(4)$ \\
\hline $\mathrm{C} 13-\mathrm{C} 14-\mathrm{C} 14 \mathrm{~A}-\mathrm{C} 15$ & $179.2(2)$ \\
\hline $\mathrm{C} 14 \mathrm{~A}-\mathrm{C} 15-\mathrm{C} 16-\mathrm{C} 17$ & $0.8(4)$ \\
\hline $\mathrm{C} 15-\mathrm{C} 16-\mathrm{C} 17-\mathrm{C} 18$ & $-0.5(4)$ \\
\hline $\mathrm{C} 16-\mathrm{C} 17-\mathrm{C} 18-\mathrm{C} 18 \mathrm{~A}$ & $-0.1(4)$ \\
\hline $\mathrm{C} 12-\mathrm{O} 11-\mathrm{C} 18 \mathrm{~A}-\mathrm{C} 14 \mathrm{~A}$ & $0.8(4)$ \\
\hline $\mathrm{C} 12-\mathrm{O} 11-\mathrm{C} 18 \mathrm{~A}-\mathrm{C} 18$ & $-179.4(2)$ \\
\hline $\mathrm{C} 15-\mathrm{C} 14 \mathrm{~A}-\mathrm{C} 18 \mathrm{~A}-\mathrm{O} 11$ & $179.6(2)$ \\
\hline $\mathrm{C} 14-\mathrm{C} 14 \mathrm{~A}-\mathrm{C} 18 \mathrm{~A}-\mathrm{O} 11$ & $-0.5(4)$ \\
\hline $\mathrm{C} 15-\mathrm{C} 14 \mathrm{~A}-\mathrm{C} 18 \mathrm{~A}-\mathrm{C} 18$ & $-0.1(4)$ \\
\hline $\mathrm{C} 14-\mathrm{C} 14 \mathrm{~A}-\mathrm{C} 18 \mathrm{~A}-\mathrm{C} 18$ & $179.7(2)$ \\
\hline $\mathrm{C} 17-\mathrm{C} 18-\mathrm{C} 18 \mathrm{~A}-\mathrm{O} 11$ & $-179.3(2)$ \\
\hline $\mathrm{C} 17-\mathrm{C} 18-\mathrm{C} 18 \mathrm{~A}-\mathrm{C} 14 \mathrm{~A}$ & $0.4(4)$ \\
\hline $\mathrm{C} 28 \mathrm{~A}-\mathrm{O} 21-\mathrm{C} 22-\mathrm{C} 23$ & $-2.9(4)$ \\
\hline $\mathrm{O} 21-\mathrm{C} 22-\mathrm{C} 23-\mathrm{C} 24$ & $1.0(4)$ \\
\hline $\mathrm{O} 21-\mathrm{C} 22-\mathrm{C} 23-\mathrm{C} 237$ & $-178.0(2)$ \\
\hline $\mathrm{C} 22-\mathrm{C} 23-\mathrm{C} 24-\mathrm{O} 24$ & $-179.2(3)$ \\
\hline $\mathrm{C} 237-\mathrm{C} 23-\mathrm{C} 24-\mathrm{O} 24$ & $-0.3(4)$ \\
\hline $\mathrm{C} 22-\mathrm{C} 23-\mathrm{C} 24-\mathrm{C} 24 \mathrm{~A}$ & $1.2(4)$ \\
\hline $\mathrm{C} 237-\mathrm{C} 23-\mathrm{C} 24-\mathrm{C} 24 \mathrm{~A}$ & $-180.0(2)$ \\
\hline $\mathrm{C} 26-\mathrm{C} 25-\mathrm{C} 24 \mathrm{~A}-\mathrm{C} 28 \mathrm{~A}$ & $0.3(4)$ \\
\hline $\mathrm{C} 26-\mathrm{C} 25-\mathrm{C} 24 \mathrm{~A}-\mathrm{C} 24$ & $-177.9(3)$ \\
\hline $\mathrm{O} 24-\mathrm{C} 24-\mathrm{C} 24 \mathrm{~A}-\mathrm{C} 28 \mathrm{~A}$ & $179.0(3)$ \\
\hline $\mathrm{C} 23-\mathrm{C} 24-\mathrm{C} 24 \mathrm{~A}-\mathrm{C} 28 \mathrm{~A}$ & $-1.3(4)$ \\
\hline $\mathrm{O} 24-\mathrm{C} 24-\mathrm{C} 24 \mathrm{~A}-\mathrm{C} 25$ & $-2.8(4)$ \\
\hline $\mathrm{C} 23-\mathrm{C} 24-\mathrm{C} 24 \mathrm{~A}-\mathrm{C} 25$ & $176.9(2)$ \\
\hline $\mathrm{C} 24 \mathrm{~A}-\mathrm{C} 25-\mathrm{C} 26-\mathrm{C} 27$ & $-0.8(4)$ \\
\hline $\mathrm{C} 25-\mathrm{C} 26-\mathrm{C} 27-\mathrm{C} 28$ & $0.0(4)$ \\
\hline $\mathrm{C} 26-\mathrm{C} 27-\mathrm{C} 28-\mathrm{C} 28 \mathrm{~A}$ & $1.3(4)$ \\
\hline $\mathrm{C} 22-\mathrm{O} 21-\mathrm{C} 28 \mathrm{~A}-\mathrm{C} 24 \mathrm{~A}$ & $2.7(4)$ \\
\hline
\end{tabular}

$\begin{array}{ll}\mathrm{C} 27-\mathrm{C} 28-\mathrm{C} 28 \mathrm{~A}-\mathrm{C} 24 \mathrm{~A} & -1.8(4) \\ \mathrm{C} 134-\mathrm{N} 133-\mathrm{C} 132-\mathrm{N} 13 & 179.2(2) \\ \mathrm{C} 134-\mathrm{N} 133-\mathrm{C} 132-\mathrm{S} 131 & 0.4(3) \\ \mathrm{C} 137-\mathrm{N} 13-\mathrm{C} 132-\mathrm{N} 133 & 178.4(3) \\ \mathrm{C} 137-\mathrm{N} 13-\mathrm{C} 132-\mathrm{S} 131 & -2.9(4) \\ \mathrm{C} 135-\mathrm{S} 131-\mathrm{C} 132-\mathrm{N} 133 & -0.5(2) \\ \mathrm{C} 135-\mathrm{S} 131-\mathrm{C} 132-\mathrm{N} 13 & -179.2(2) \\ \mathrm{C} 132-\mathrm{N} 133-\mathrm{C} 134-\mathrm{C} 135 & -0.1(4) \\ \mathrm{N} 133-\mathrm{C} 134-\mathrm{C} 135-\mathrm{C} 136 & -179.3(3) \\ \mathrm{N} 133-\mathrm{C} 134-\mathrm{C} 135-\mathrm{S} 131 & -0.3(4) \\ \mathrm{C} 132-\mathrm{S} 131-\mathrm{C} 135-\mathrm{C} 134 & 0.4(2) \\ \mathrm{C} 132-\mathrm{S} 131-\mathrm{C} 135-\mathrm{C} 136 & 179.5(2) \\ \mathrm{C} 132-\mathrm{N} 13-\mathrm{C} 137-\mathrm{O} 131 & 2.8(4) \\ \mathrm{C} 132-\mathrm{N} 13-\mathrm{C} 137-\mathrm{C} 13 & -176.9(2) \\ \mathrm{C} 12-\mathrm{C} 13-\mathrm{C} 137-\mathrm{O} 131 & -5.8(4) \\ \mathrm{C} 14-\mathrm{C} 13-\mathrm{C} 137-\mathrm{O} 131 & 176.1(3) \\ \mathrm{C} 12-\mathrm{C} 13-\mathrm{C} 137-\mathrm{N} 13 & 173.8(2) \\ \mathrm{C} 14-\mathrm{C} 13-\mathrm{C} 137-\mathrm{N} 13 & -4.2(4) \\ \mathrm{C} 234-\mathrm{N} 233-\mathrm{C} 232-\mathrm{N} 23 & 179.0(2) \\ \mathrm{C} 234-\mathrm{N} 233-\mathrm{C} 232-\mathrm{S} 231 & 0.5(3) \\ \mathrm{C} 237-\mathrm{N} 23-\mathrm{C} 232-\mathrm{N} 233 & 179.0(3) \\ \mathrm{C} 237-\mathrm{N} 23-\mathrm{C} 232-\mathrm{S} 231 & -2.6(4) \\ \mathrm{C} 235-\mathrm{S} 231-\mathrm{C} 232-\mathrm{N} 233 & -0.4(2) \\ \mathrm{C} 235-\mathrm{S} 231-\mathrm{C} 232-\mathrm{N} 23 & -178.9(2) \\ \mathrm{C} 232-\mathrm{N} 233-\mathrm{C} 234-\mathrm{C} 235 & -0.3(4) \\ \mathrm{N} 233-\mathrm{C} 234-\mathrm{C} 235-\mathrm{C} 236 & -178.9(3) \\ \mathrm{N} 233-\mathrm{C} 234-\mathrm{C} 235-\mathrm{S} 231 & 0.0(3) \\ \mathrm{C} 232-\mathrm{S} 231-\mathrm{C} 235-\mathrm{C} 234 & 0.2(2) \\ \mathrm{C} 232-\mathrm{S} 231-\mathrm{C} 235-\mathrm{C} 236 & 179.2(2) \\ \mathrm{C} 232-\mathrm{N} 23-\mathrm{C} 237-\mathrm{O} 231 & 0.0(4) \\ \mathrm{C} 232-\mathrm{N} 23-\mathrm{C} 237-\mathrm{C} 23 & -179.7(2) \\ \mathrm{C} 22-\mathrm{C} 23-\mathrm{C} 237-\mathrm{O} 231 & -0.6(4) \\ \mathrm{C} 24-\mathrm{C} 23-\mathrm{C} 237-\mathrm{O} 231 & -179.5(3) \\ \mathrm{C} 22-\mathrm{C} 23-\mathrm{C} 237-\mathrm{N} 23 & 179.2(2) \\ \mathrm{C} 24-\mathrm{C} 23-\mathrm{C} 237-\mathrm{N} 23 & 0.3(4) \\ & \end{array}$

Hydrogen-bond geometry $\left(\AA,{ }^{\circ}\right)$

\begin{tabular}{lllll}
\hline$D-\mathrm{H} \cdots A$ & $D-\mathrm{H}$ & $\mathrm{H} \cdots A$ & $D \cdots A$ & $D-\mathrm{H} \cdots A$ \\
\hline $\mathrm{N} 13-\mathrm{H} 13 \cdots \mathrm{O} 14$ & $0.80(4)$ & $1.99(4)$ & $2.671(3)$ & $143(4)$ \\
$\mathrm{C} 12-\mathrm{H} 12 \cdots \mathrm{O} 24^{\mathrm{i}}$ & 0.95 & 2.27 & $2.963(4)$ & 129 \\
$\mathrm{C} 15-\mathrm{H} 15 \cdots \mathrm{O} 23^{\mathrm{ii}}$ & 0.95 & 2.43 & $3.353(4)$ & 164 \\
$\mathrm{C} 136-\mathrm{H} 13 C \cdots \mathrm{O} 13^{\mathrm{iii}}$ & 0.98 & 2.51 & $3.449(4)$ & 162 \\
$\mathrm{~N} 23-\mathrm{H} 23 \cdots \mathrm{O} 24$ & $0.82(4)$ & $2.05(3)$ & $2.697(3)$ & $136(3)$ \\
$\mathrm{C} 22-\mathrm{H} 22 \cdots \mathrm{O} 14^{\mathrm{ii}}$ & 0.95 & 2.19 & $2.999(4)$ & 142 \\
$\mathrm{C} 25-\mathrm{H} 25 \cdots \mathrm{O} 13^{\text {iv }}$ & 0.95 & 2.48 & $3.352(4)$ & 153
\end{tabular}

Symmetry codes: (i) $x+1,-y+1 / 2, z+1 / 2$; (ii) $x,-y+1 / 2, z+1 / 2$; (iii) $-x+1,-y+1,-z+1$; (iv) $x-1,-y+1 / 2, z-1 / 2$. 